




\section{الاحتجاج بالأمثال الجاهلية في النحو والصَّرف، دراسة وصفية تحليلية}















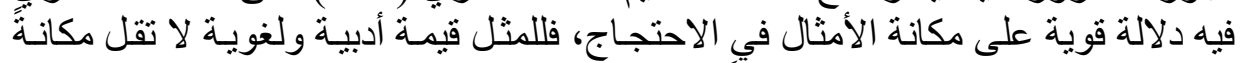





\section{ABSTRACT:}

The study dealt with "invoking pre-Islamic proverbs in grammar and morphing, its descriptive analytical study" ..It aimed at identifying the role that the Arab proverb plays in grammatical and morphological performance. The study followed the descriptive analytical approach. There is no disagreement about invoking the Arab proverb, for security in terms of time or place. The invocation of the same is similar to invoking poetry on the one hand that all of the two matters in it may be necessary in order to be expelled with this role. The introduction of the prose "proverb" to the poetic witness is a strong indication of the sources of the protest, as if it was said to fulfill the grammatical and morphological purposes without the literary purposes that it depicts and is based on it. 




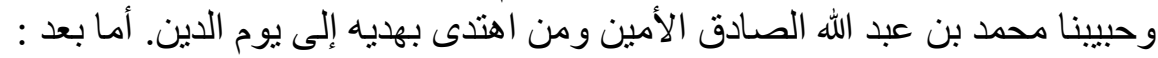


ما في نفوسهم من مشاعر و وعو اطف وأفر وأحاسيس.



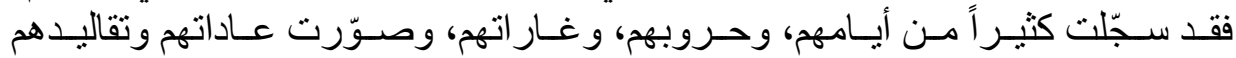





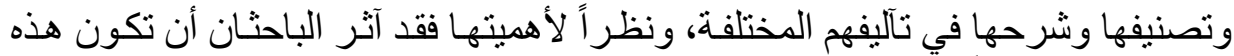

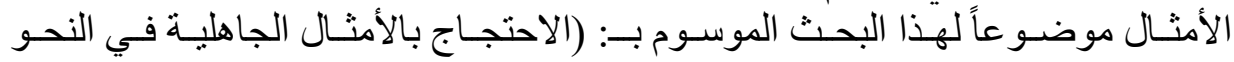

$$
\text { و الصرف). }
$$

\section{أهمية الموضوع ودوافع اختياره}







ثانياً : أهمية الأمثال اللغوية، فهي مصدر أصيل من مصادر الاحتجاج في اللغـة







$$
\text { أهداف البحث : }
$$

يهدف هذا البحث إلى تحقيق الأهداف الآتية :

أولاً: بيان أوجه الاحتجاج بالأمثال، وتوضيح قيمتها اللغوية.

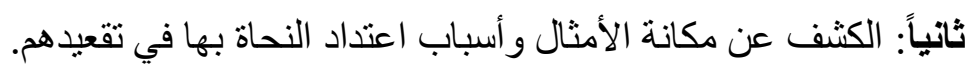
ثالثاً: إبراز معاني الأمثال الجاهلية ودلالاتها اللغوية والنحوية و الصرفية.

$$
\text { منهج البحث: آبرلث }
$$

سـارت هذه الدر اسـة وفق المـنهج الوصفي؛ لأنَّهـ الأنسـب لطبيعتهـا، حيـث يجمـع 79 






الار اسات السابقة









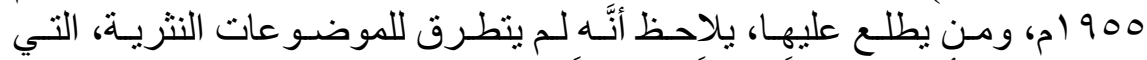



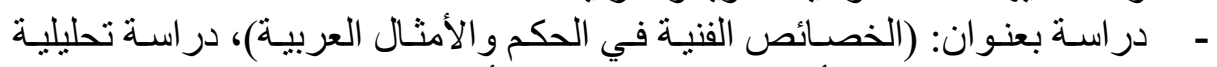



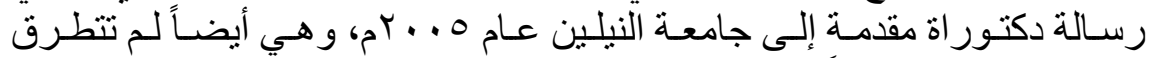
لموضوع بحثنا تفصيلاً. رسالة ماجستير بعنوان: (الأمثنال في القرآن الكريم)، مقدمـة من الدارس: محمد






عام 990 ام، و هي دراسة تطبيقية للأمثال في الحديث النبوي الثريف.

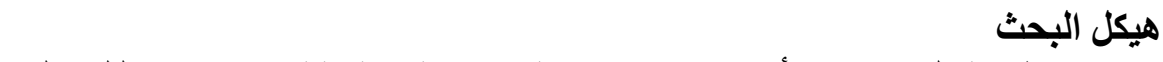
اقتضت طبيعة الموضوع، أن يكون في مقدمة وخاتمـة، وثثلاثة محاور ، وذلك على النحو الآتي: - n النيت المحور الأول: تعريف المثل في اللغة والاصطلاح. المحور الثاني: الاحتجاج بالمثل في القضايا النحوية.



المحور الأول: تعريف المثل في اللغة والاصطلاح






و الممثنّل المصوَّر على مثنال غيره، و المثنال: وضع شيء ما ليحتذى به (').

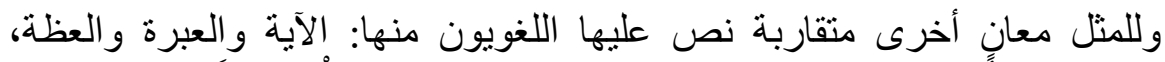

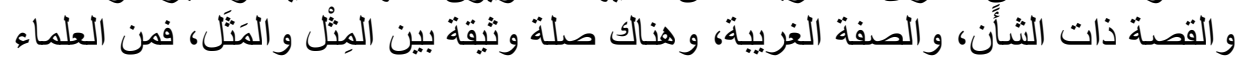

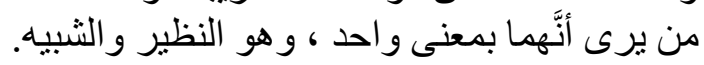

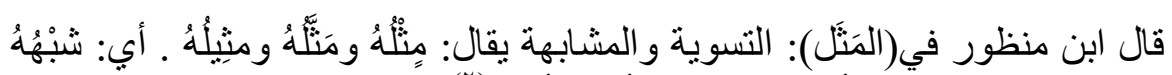

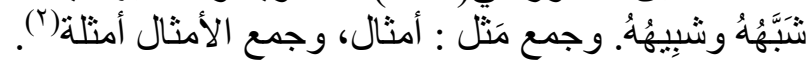

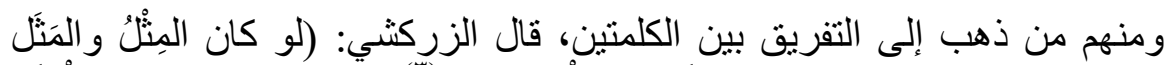

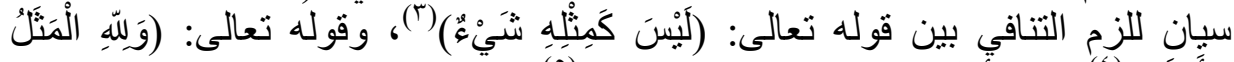



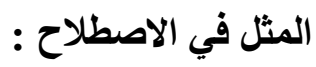

قال ابن عبد ربه يصف الأمثال: (وشي الكلام وجوهر اللفظ وجلي المعاني، فهي














الشعوب التي تعكس حاجات الأفر اد الثخصية في دلالة اجتماعية، إنسانية شاملة.

(1)- ابن فارس (أبو الحسين أحمد بن زكريا)، معجم مقاييس اللغة، تحقيق عبدالسلام هارون، مكتبة

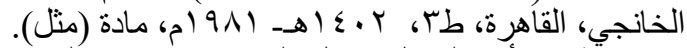







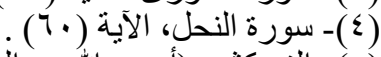



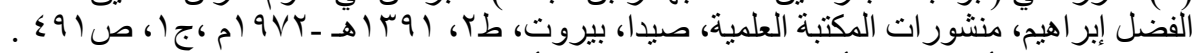

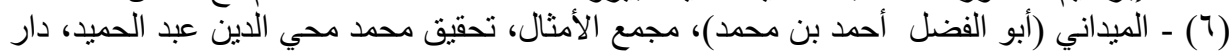

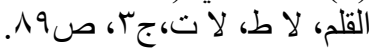
(V) 
أما ابن رشيق فيقول عن المثل إنَّه سمي كذلك: (لأنه مانلّ لخاطر الإنسان أبداً،

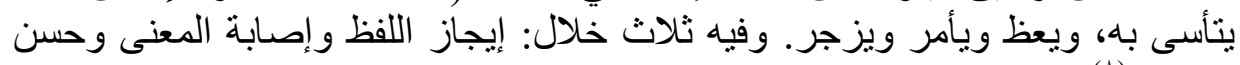
التشبيه)(^)

وها هو الراغب الأصبهاني يبسط الكلام في معرض حديثه عن الأمثال بقوله:

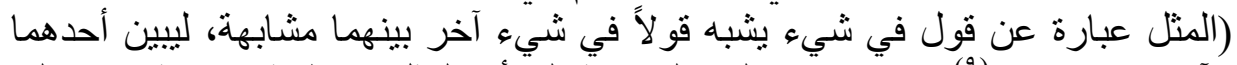

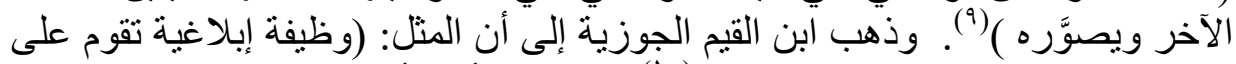

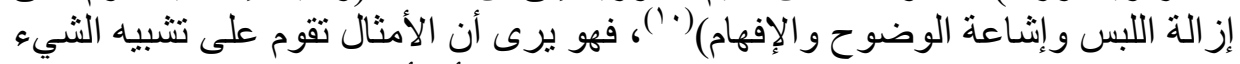

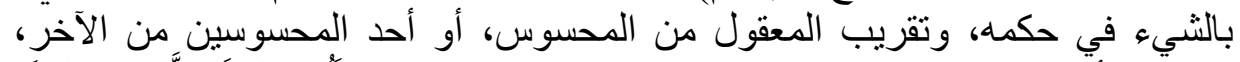

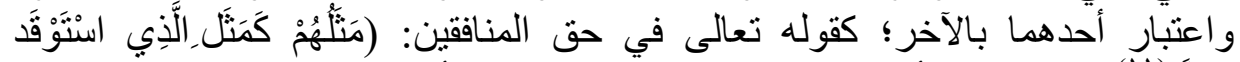

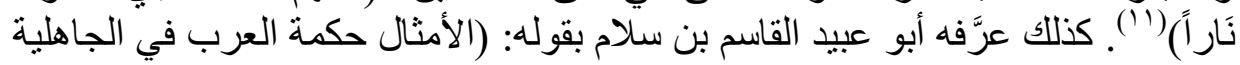

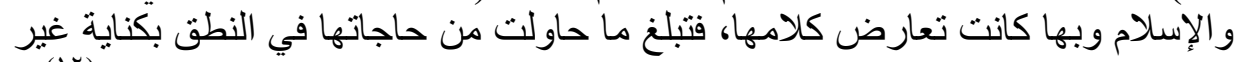

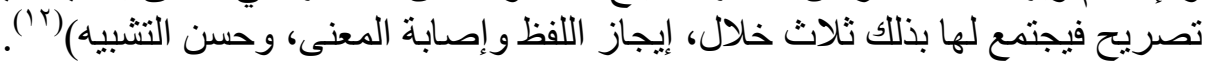






وبيان في الأسلوب وروعة في التصوير.

\section{المحور الثاني: الاحتجاج بالأمثال في القضايا النحوية}











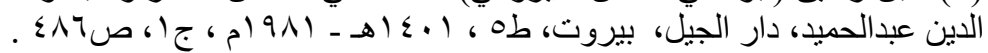

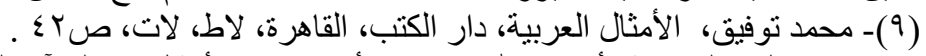
(• ( )- ابن القيم الجوزية (أبو عبدالله محمد بن أبي بكر)، الأمثال في القرآن الكئ الكريم، دار العلم، القاهرة،

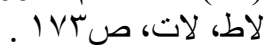

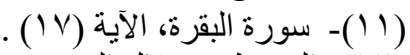

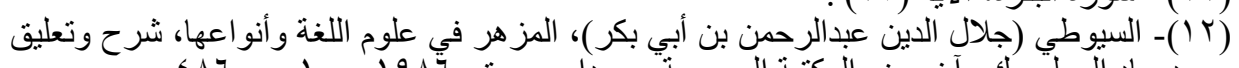

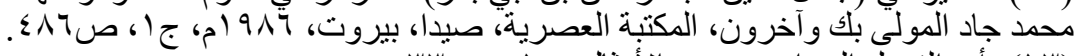

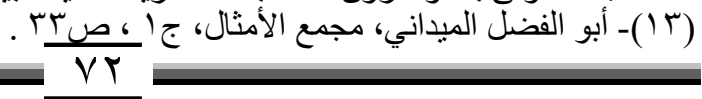




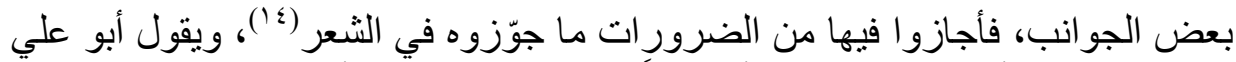

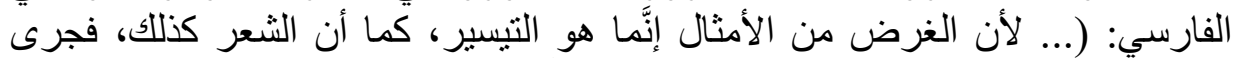

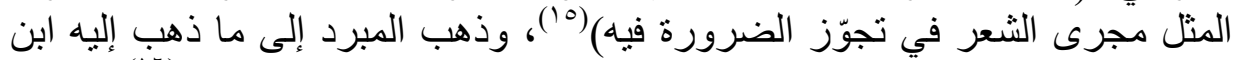

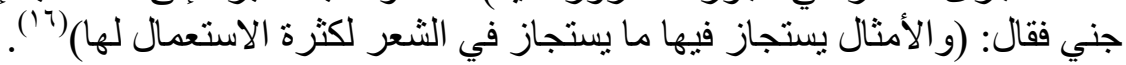

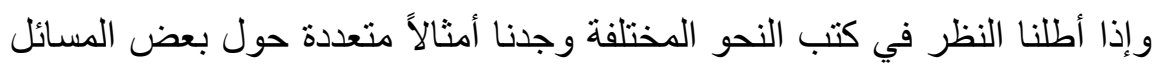

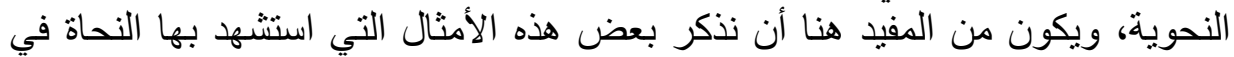

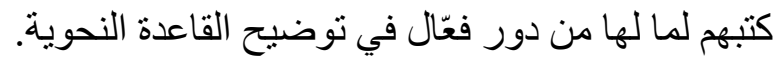

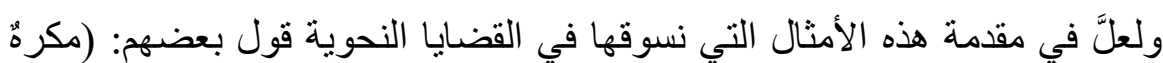

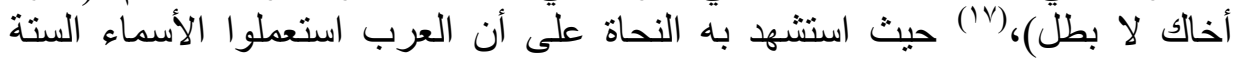

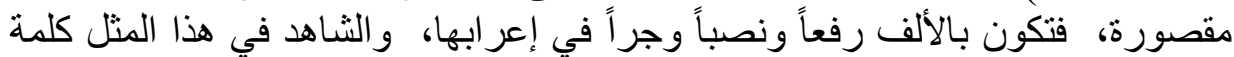

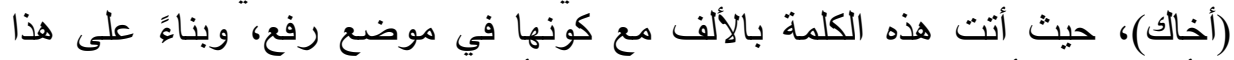

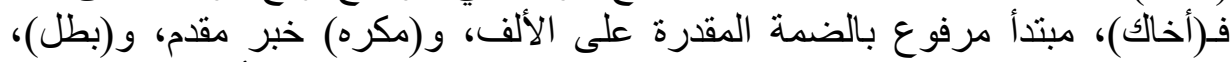

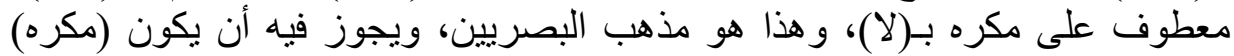

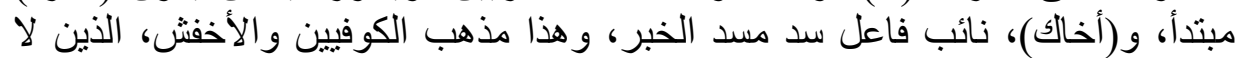

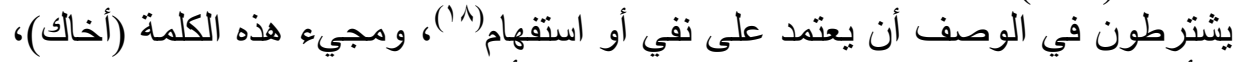

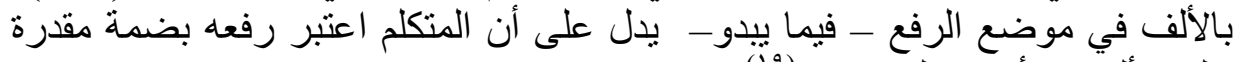
على الألف كالأسماء المقصورة الرفع فو (19).

( ) ()- محمد إبراهيم عبادة، عصور الاحتجاج في الشعر العربي، دار إحياء التراث العربي، القاهرة، ص ص (0) - المبرد (أبو العباس محمد بن بزيد، عبد الأكبر الأزدي)، المحتسب، تحقيق أحمد الدالي، دار

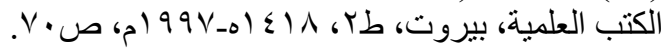



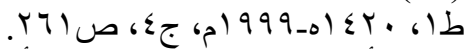

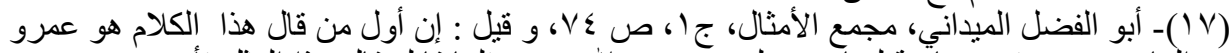

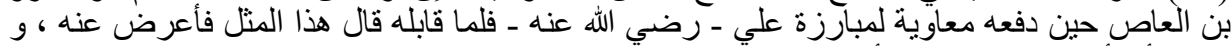

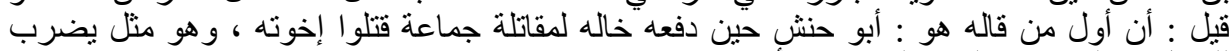

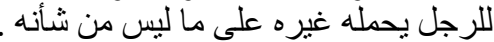

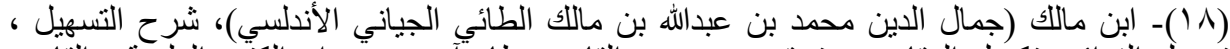

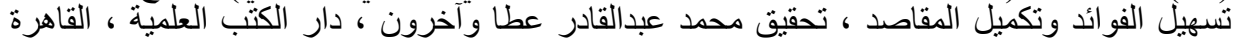

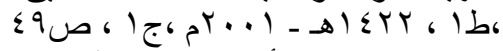

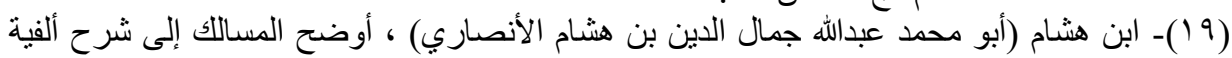

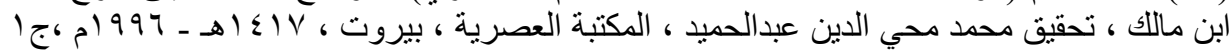




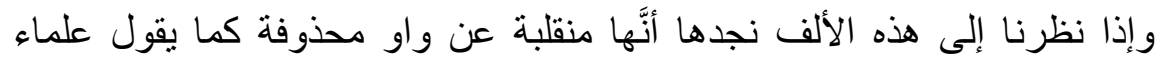

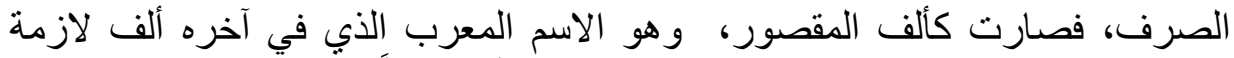

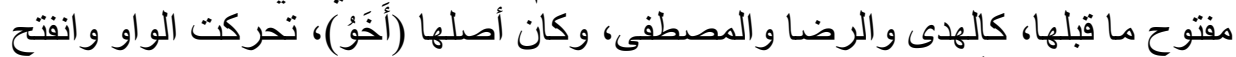

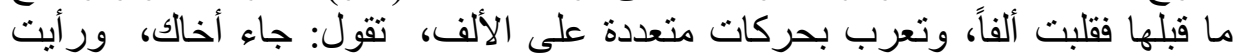

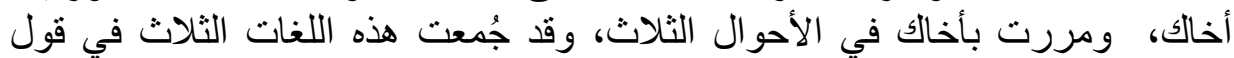

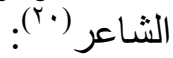

\section{إن أباها، وأبا أباها * قـ بلغا من المجد غايتاها}

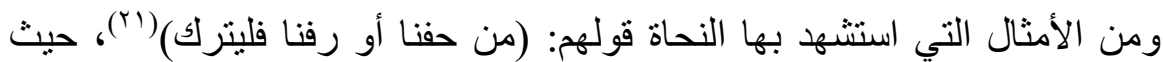

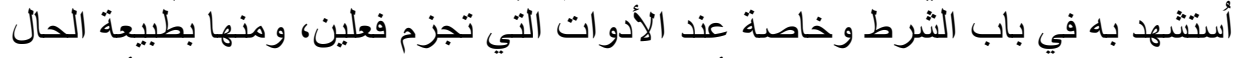

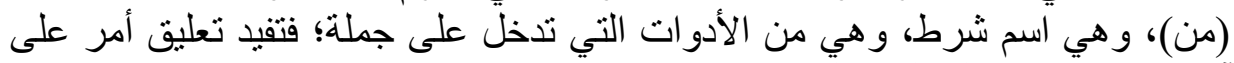

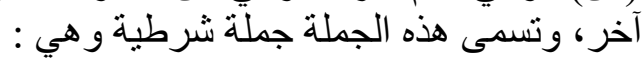

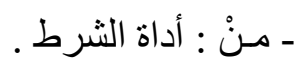

ـ حفنا : مكرّنة من الفعل و الفاعل في محل جزم جملة فعل الثرط، أو رفنا جملة معطوفة على الجملة التي قبلها. ـ فليترك : جملة جو اب الشرط، ويلاحظ على هذه الجملة ما يلي:

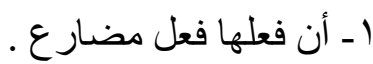

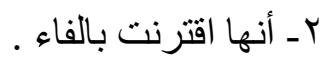

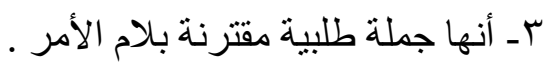

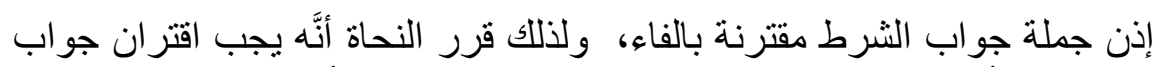

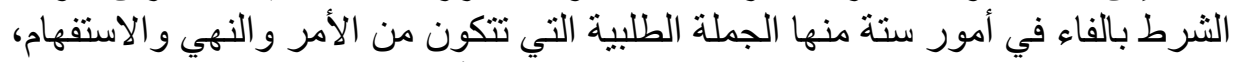

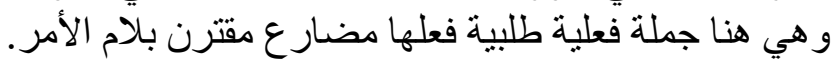

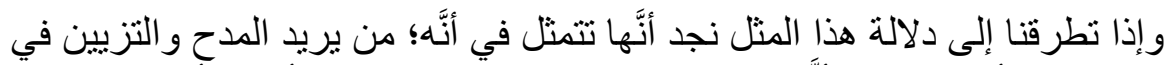

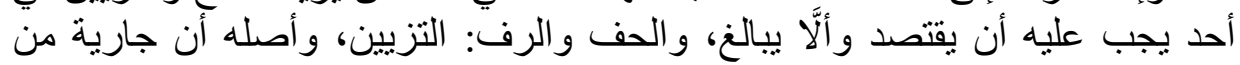

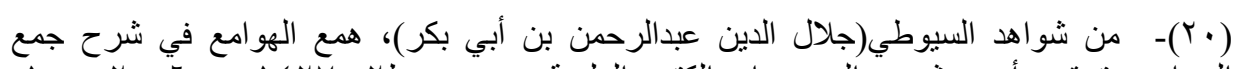

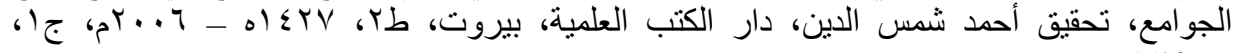

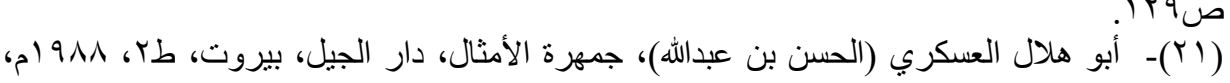


الأعر اب عثرت على نعامة قد غصت بصمغة فاحتملتها وقالت(r')

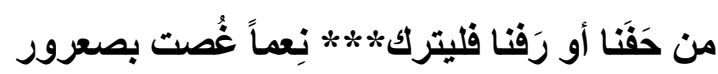

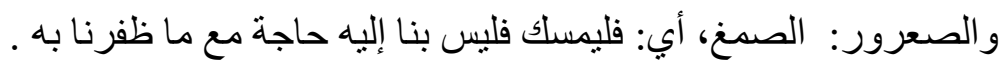

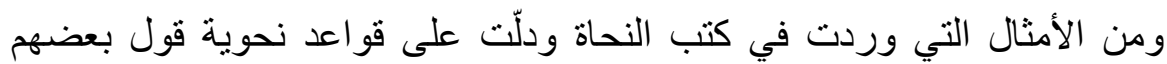

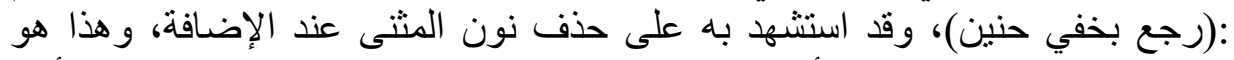

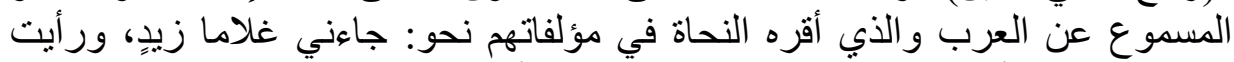

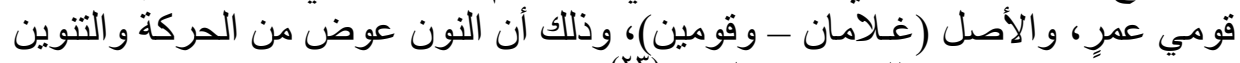

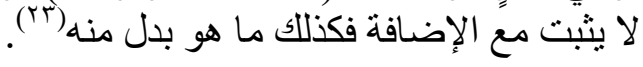

$$
\text { وقد تحذف نون المثنى تقصير اً كما في قول الثاعر (ع؟r): }
$$

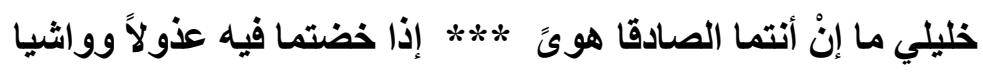

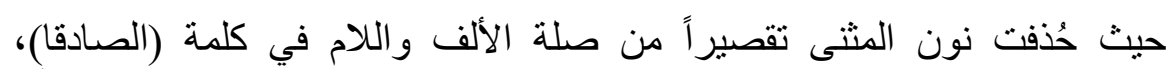

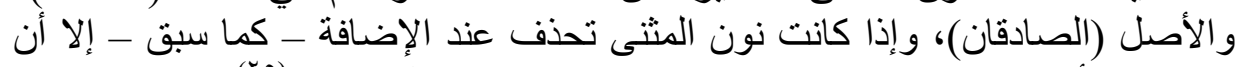

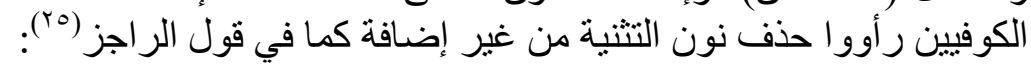

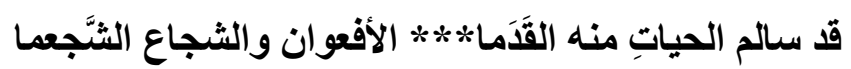

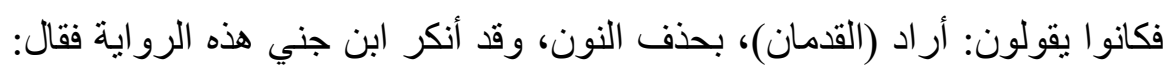

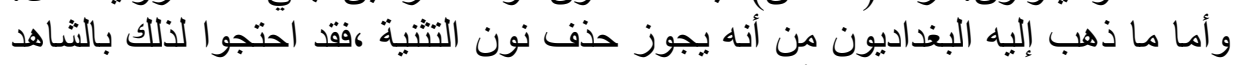

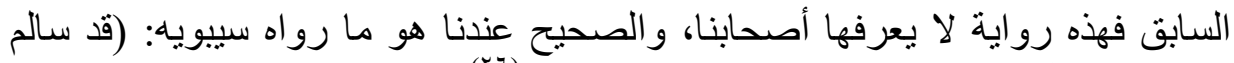

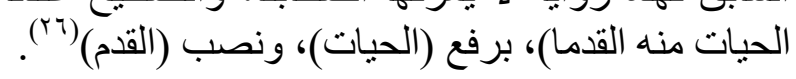

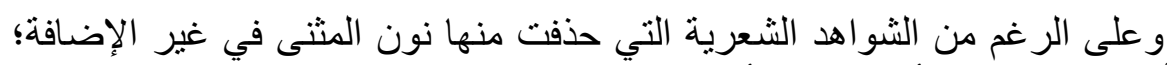

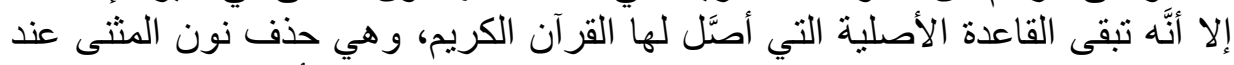

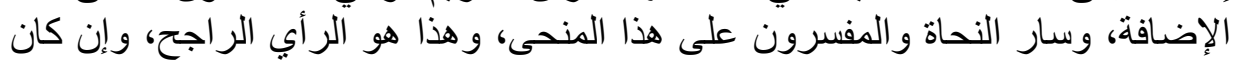

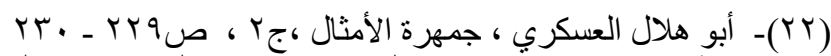

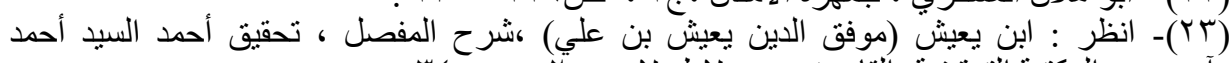

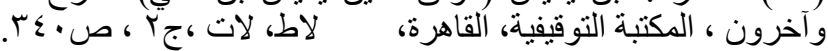

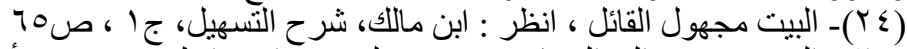

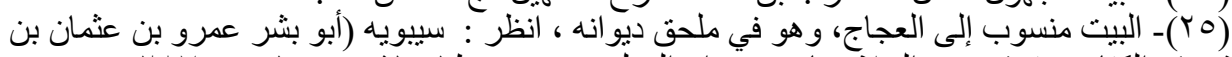

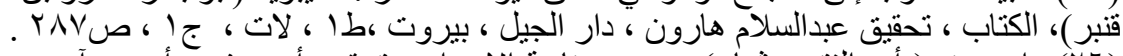

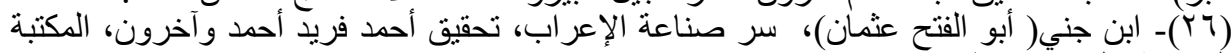

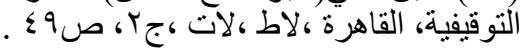




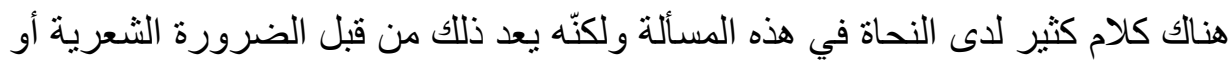

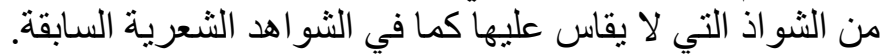

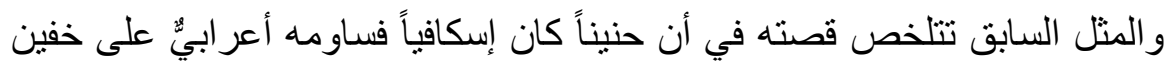

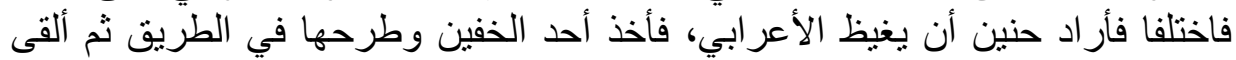

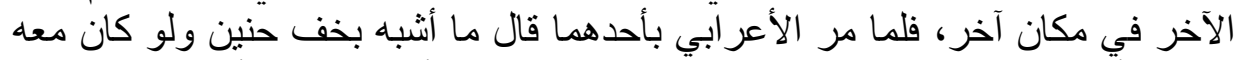

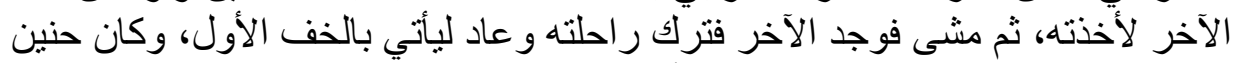

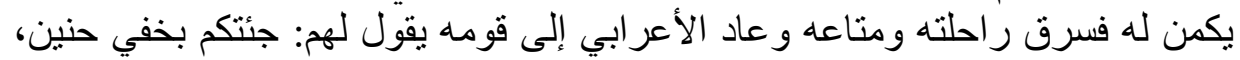
ويضرب هذا المثل لمن خاب مسعاه.

وون الأمثال التي تبيّن حضور المثل العربي في تقوية القاعدة النحوية لدى النحاة النحاة

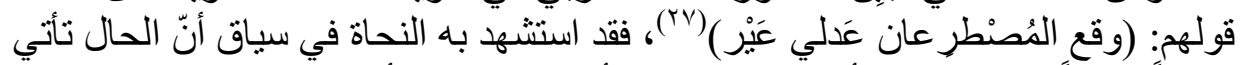

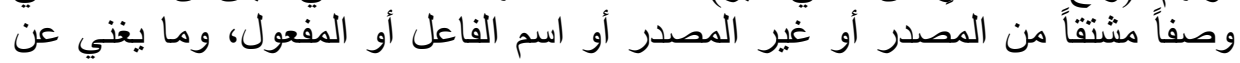

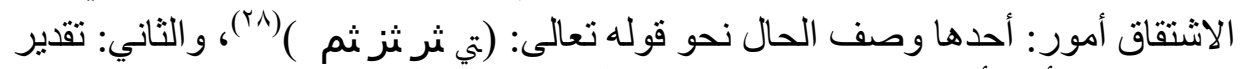

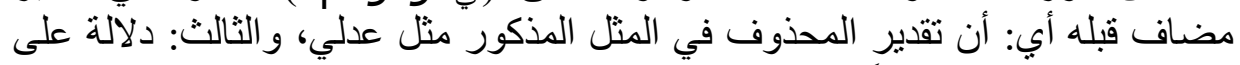

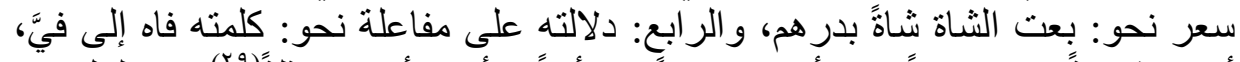

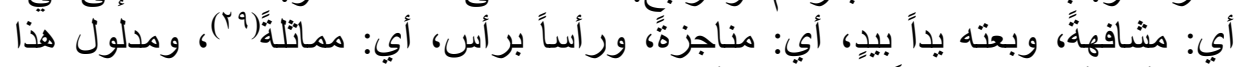

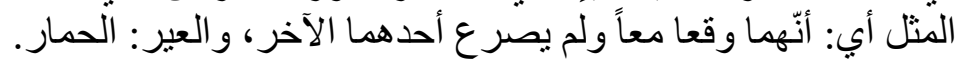

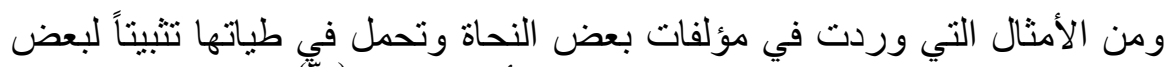

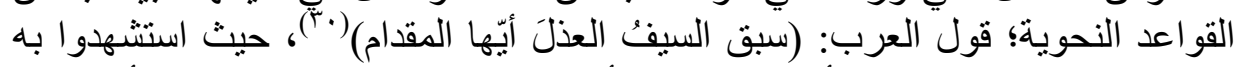

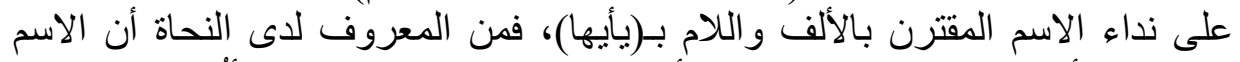

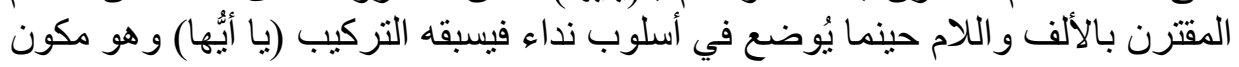
من الآتي: - من

- يـا : أداة نداء حرف مبني لا محل له من الإعراب . ـ أي : منادى مبني على الضم . - ها : للتنبيه .

وحُذف حرف النداء (يا)، في قولهم: (أيها المقدام)، وهنا حكم خاص يختص بهذا

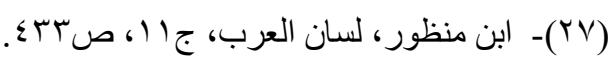

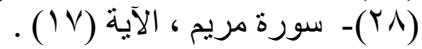

(Y9)

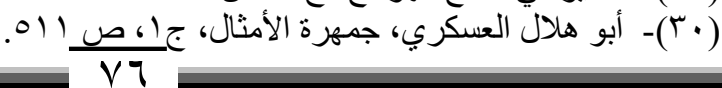


الحرف دون أخو اته من أدوات النداء، فالأصل في حرف النداء أن يكون مذكور اً، و هذا

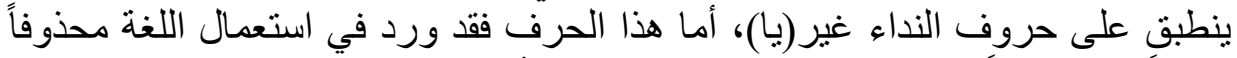

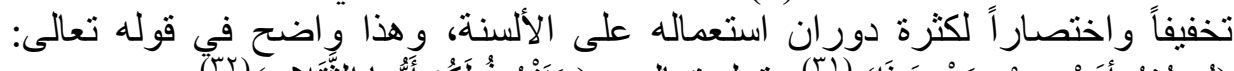

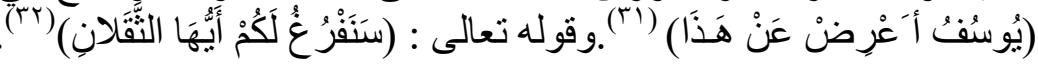

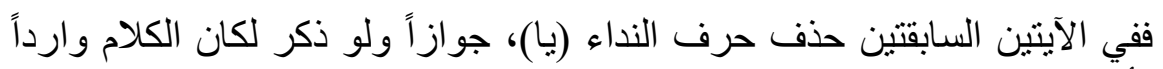

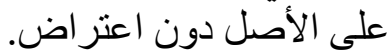

ولكن حذف حرف النداء (يا)، يكون واجباً في كلمة (اللهم)، وهي مكونة من لفظ

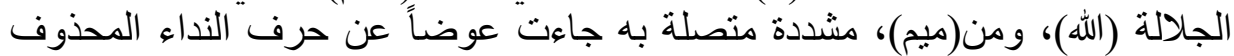

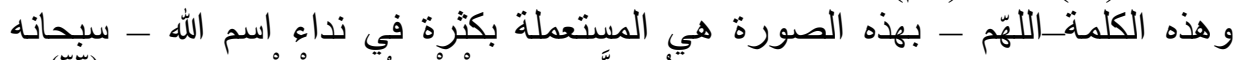

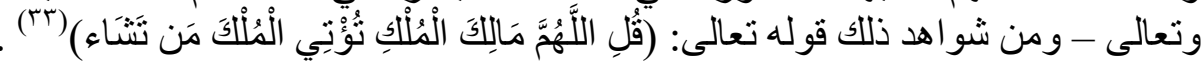

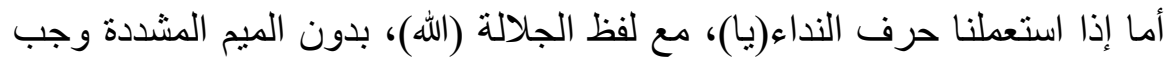

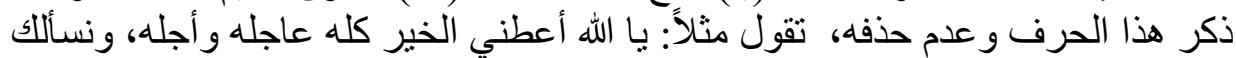

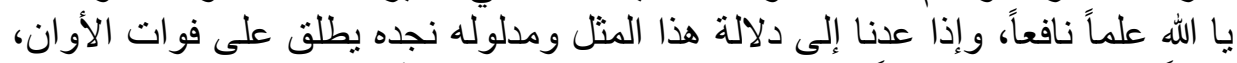

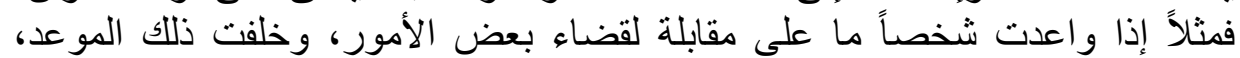

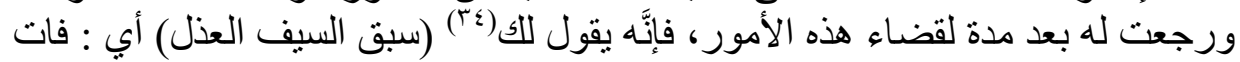

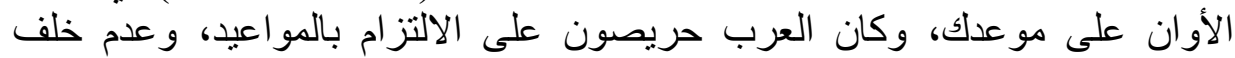

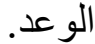

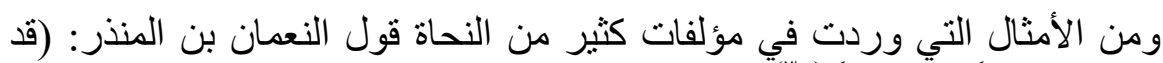

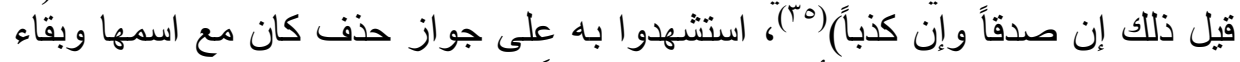

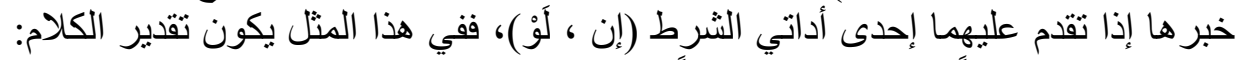

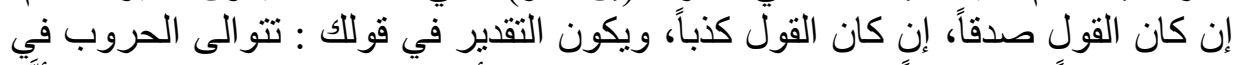

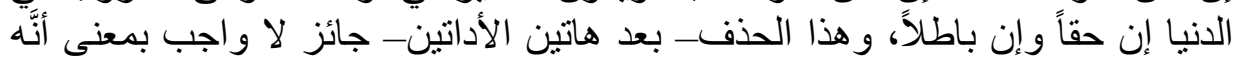

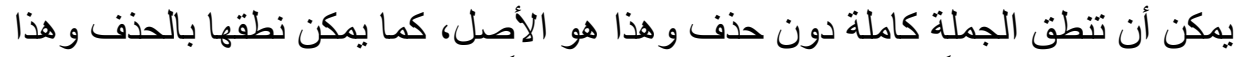

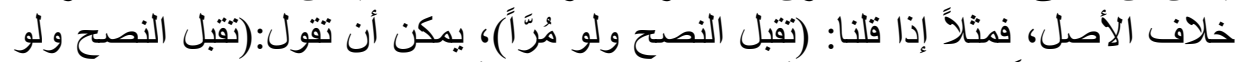

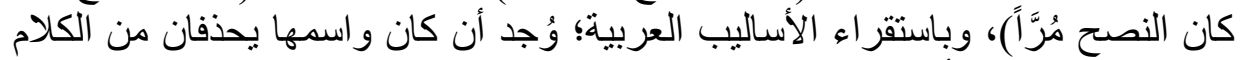
إذا تقدم عليها إحدى أداتي الثرط أنرط (إن ، لو ).

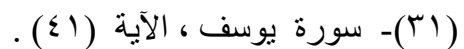

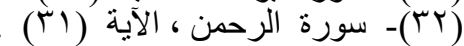

(YT)

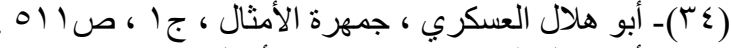

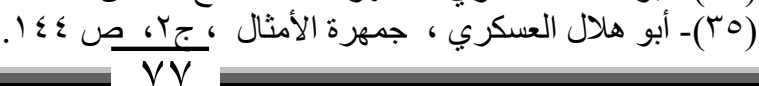




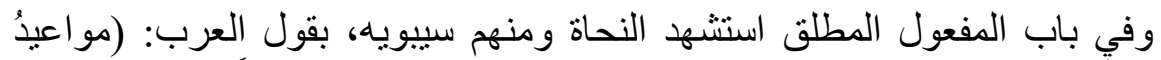

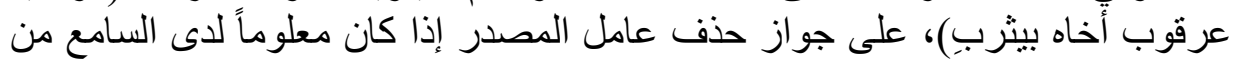

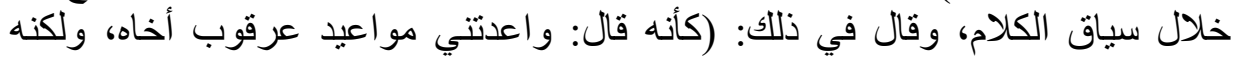

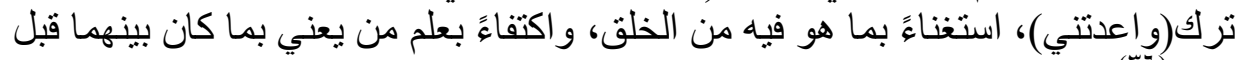
ذلك)( ذر)

وفي باب النداء استشهح الكوفيون بالمثل: (أصبح ليل)، و(افتد مخنوق)، و و(أطرق

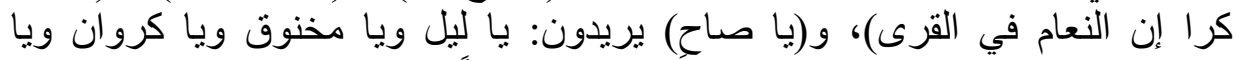

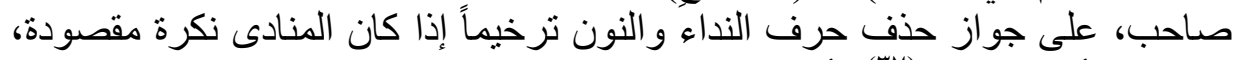

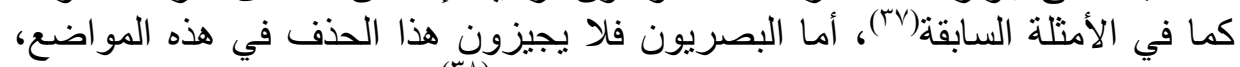

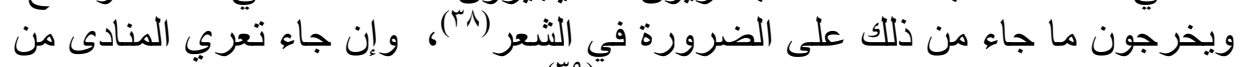

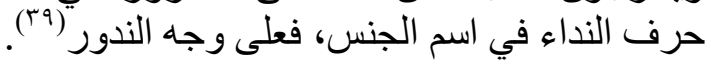

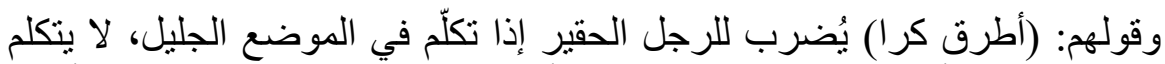

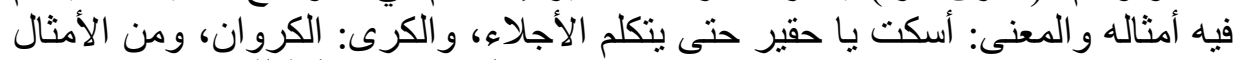

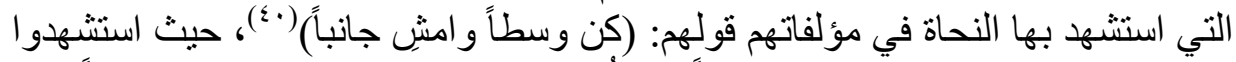

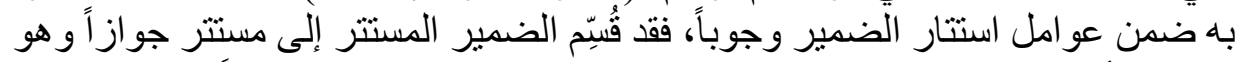

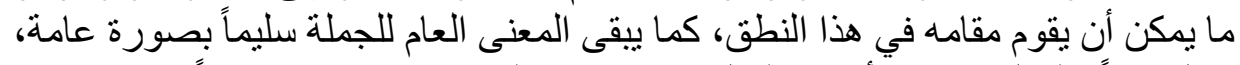

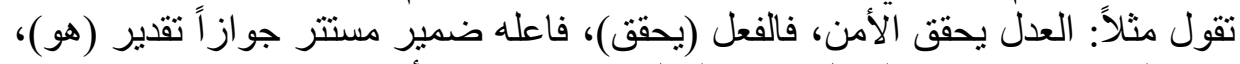
ومن الممكن ظهور هذا الفاعل هكذا: العدل يحقق فرضن الأنه الأمن.

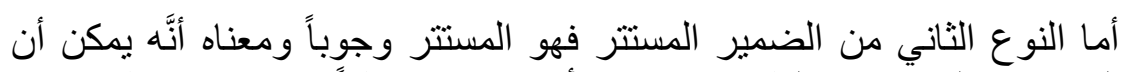

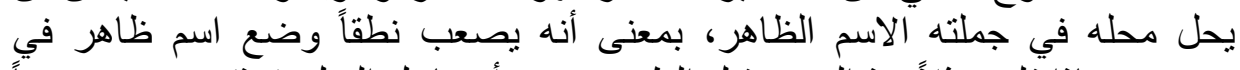

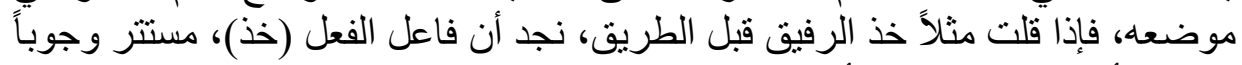

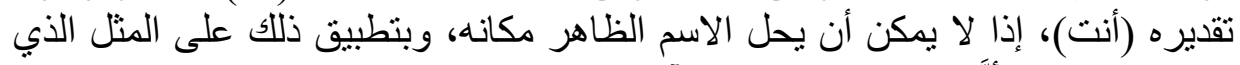

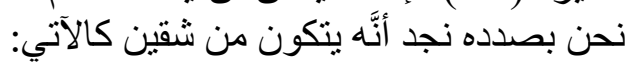
ـ الثق الأول: كن وسطاً، وهو يتكون أيضاً من:

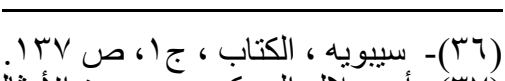

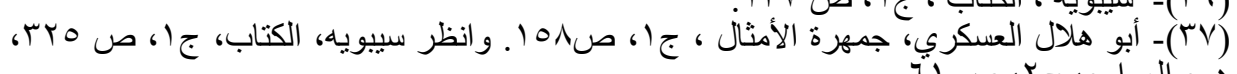

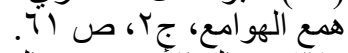

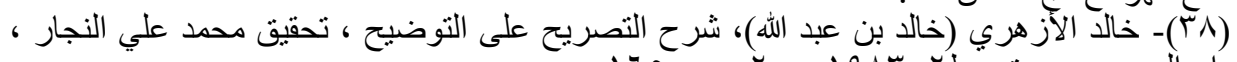

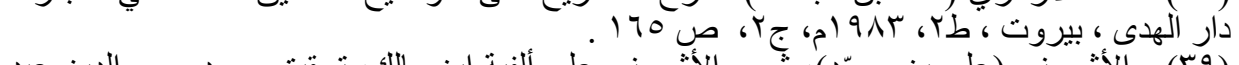

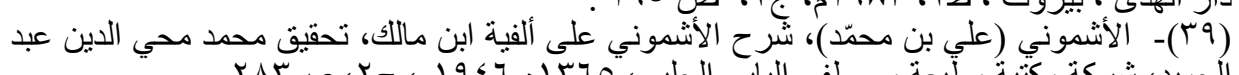

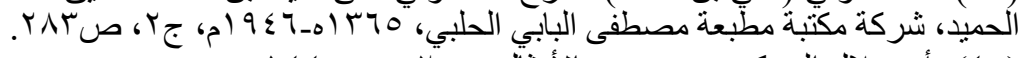

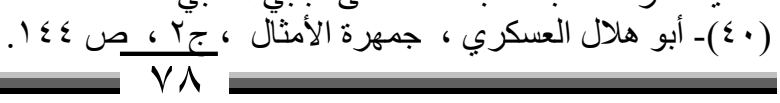


ا ـ الفعل كن، و هو بصيغة الأمر من كان الناقصة التي تحتاج إلى اسم وخبر لها .

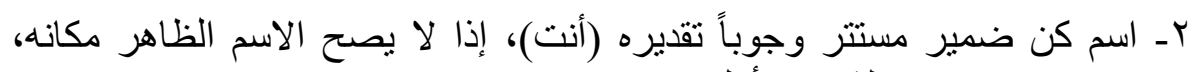

$$
\text { وهذا هو موضع الثـاهد الأول. }
$$

r- وسطاً خبر كن منصوب بالفتحة الظاهرة، وهذه جملة بسيطة ذات معنى.

ـ الثق الثاني: وامش جانباً، وهو يتكون بدوره من الآتي:

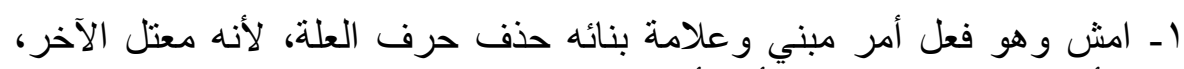

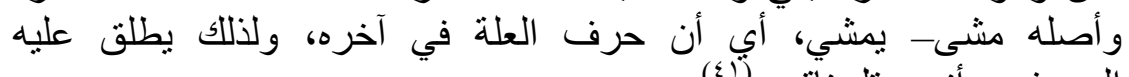

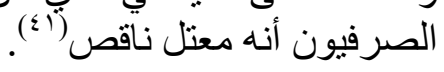

r- فاعل ( امش)، ضمير مستتر وجوباً تقديره(أنت)، إذ لا يصح وضع النع الاسم

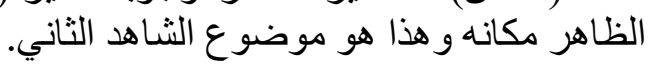

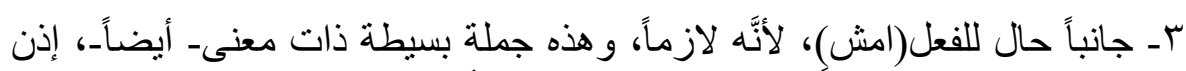

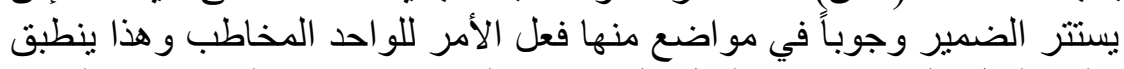

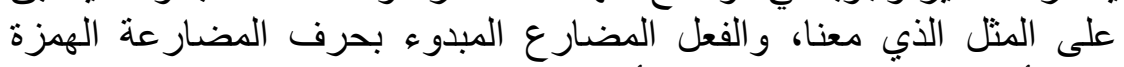

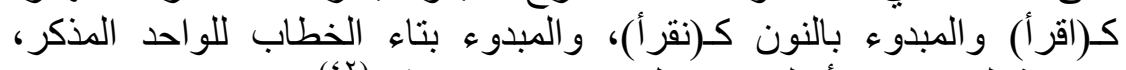
وصيغة التعجب (ما أفعله)، وفاعل (خلا و وعدا وحانشا) (باء). و هذا المثل بشقيه تتمثل دلالته في أنّه يجب عليك أن تخالط الناس كي تعيش في في وني

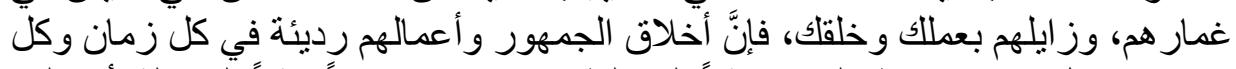

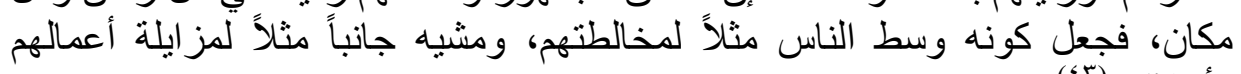
وأخلاقهم (זن)

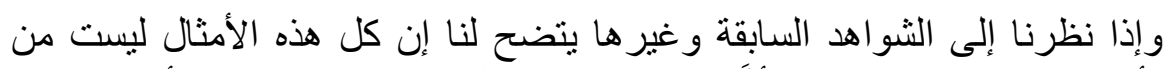

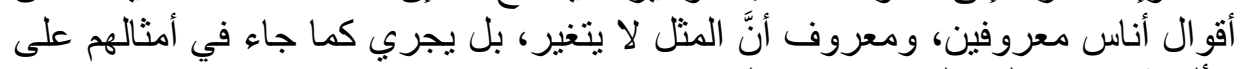

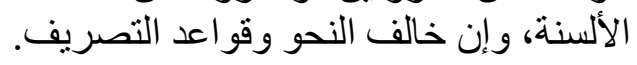

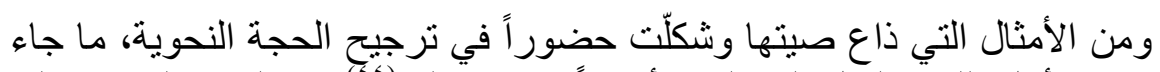

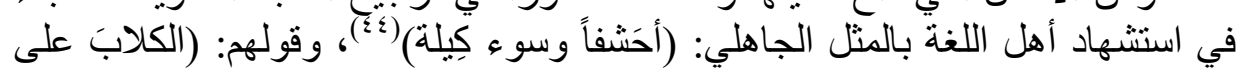

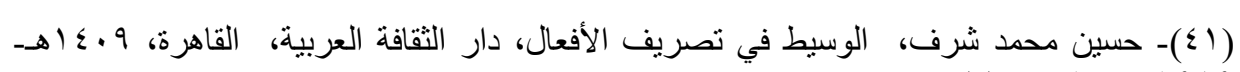

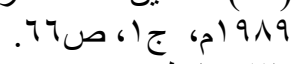

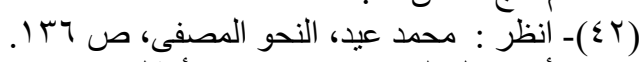
( $\vee 9$

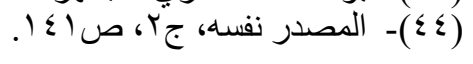




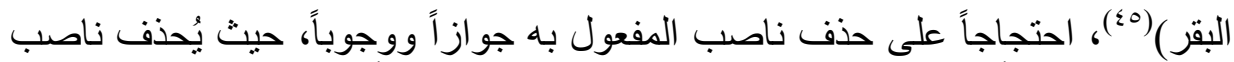

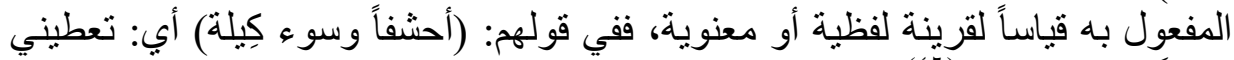

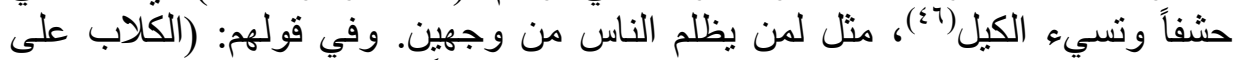

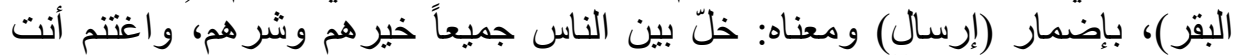

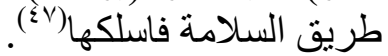

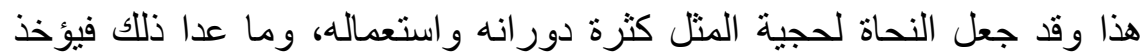

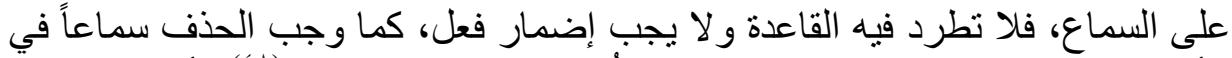

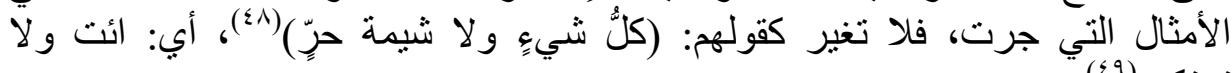

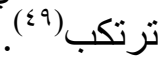

وفي باب ما يجوز تقديمه من المضمر على الظاهر إذا كان اسماً أو فعلاً؛ أجاز

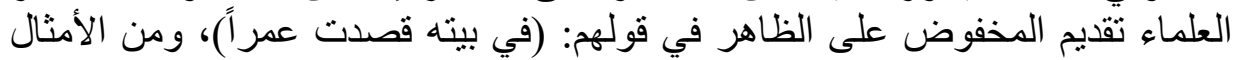

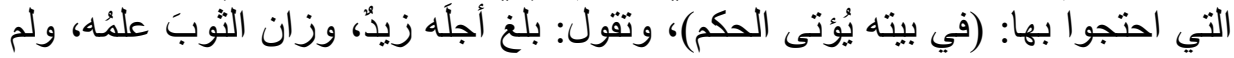

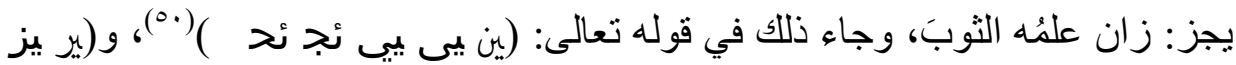

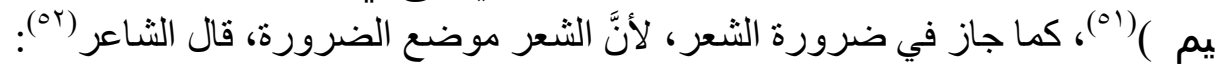

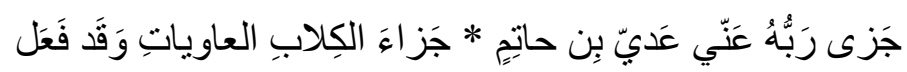

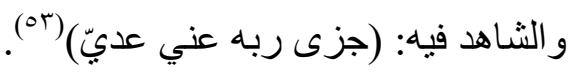

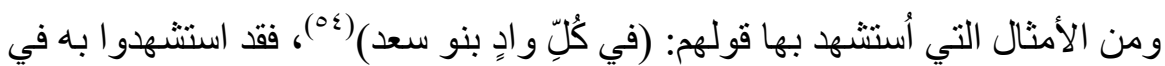

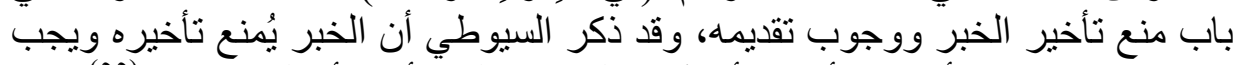

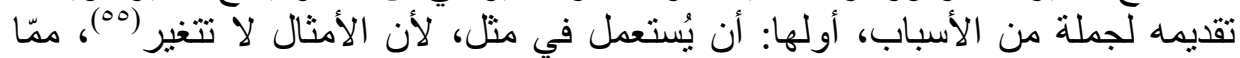

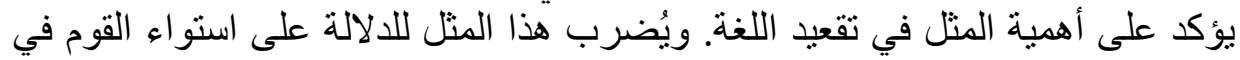

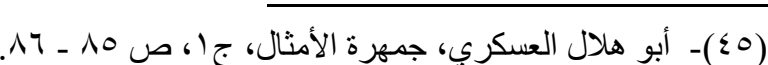

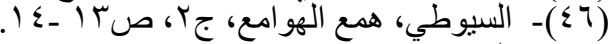

$$
\begin{aligned}
& \text { ) }
\end{aligned}
$$

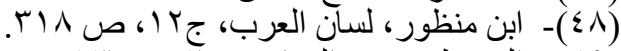

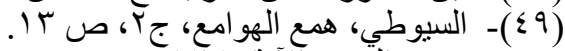

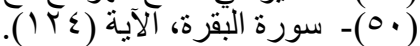

$$
\begin{aligned}
& \text { (0) } \\
& \text { VIV) }
\end{aligned}
$$

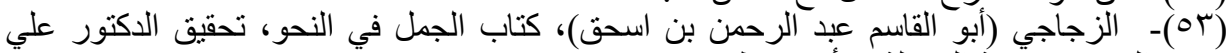

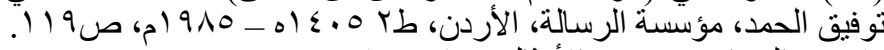

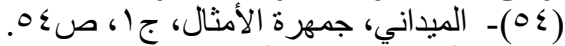

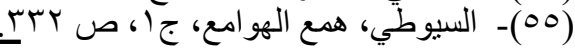




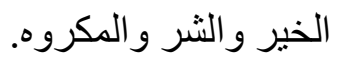

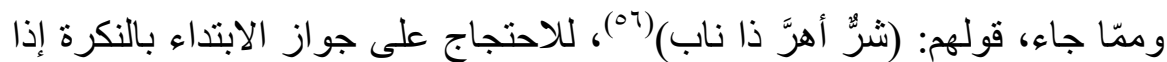

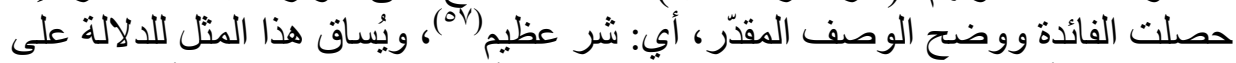

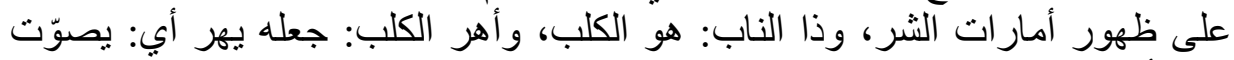

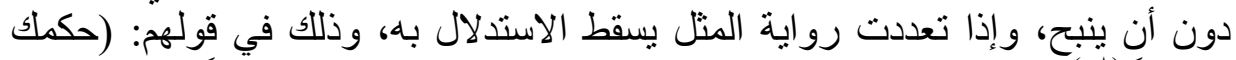

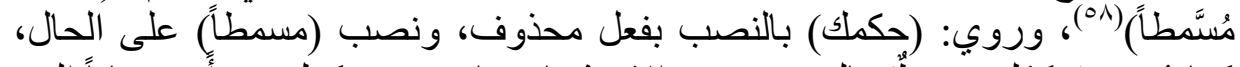

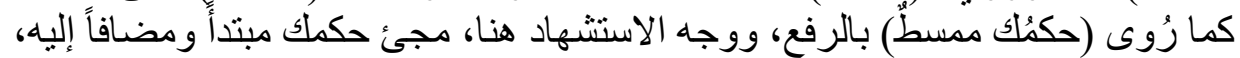

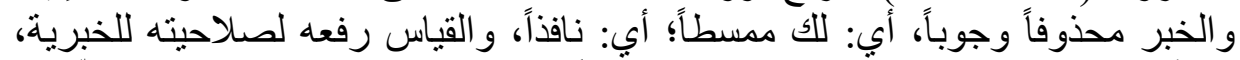

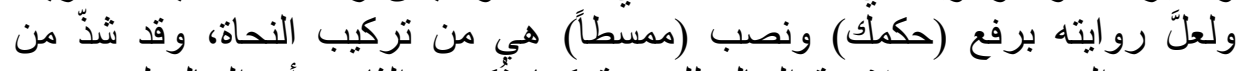

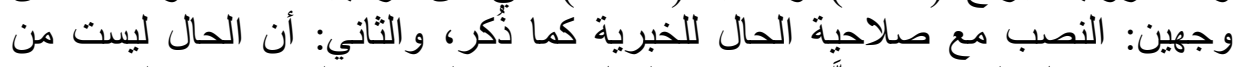

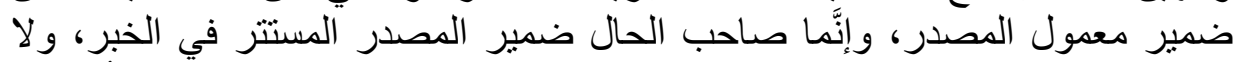

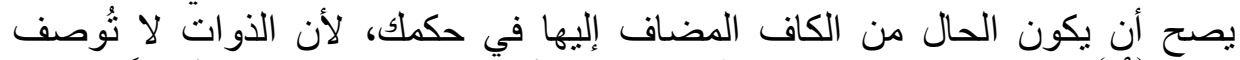

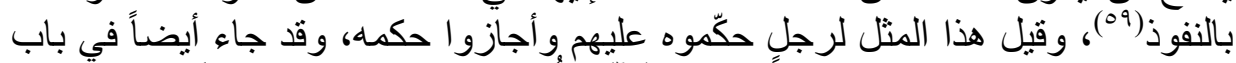

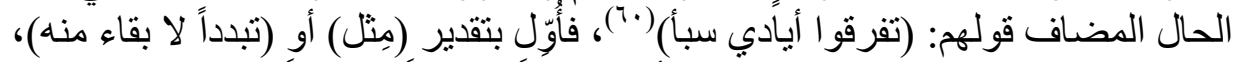

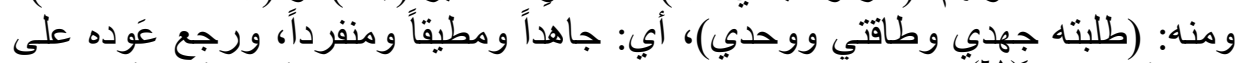

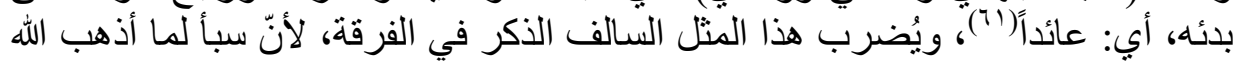

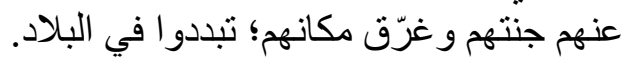

\section{المحور الثالث: الاحتجاج بالأمثال في القضايا الصرفية:}

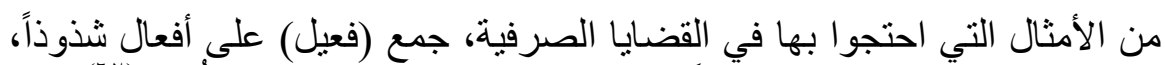

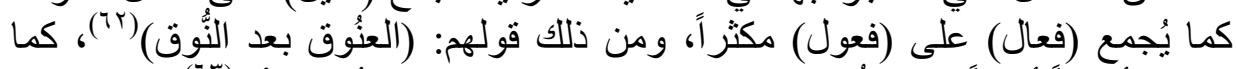

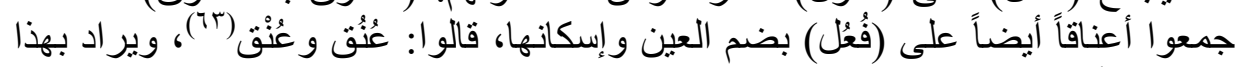

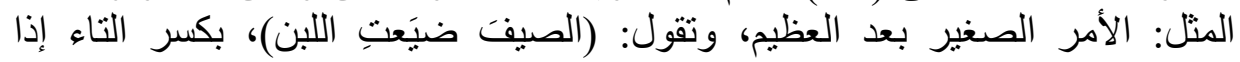

\section{(07)

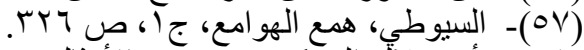

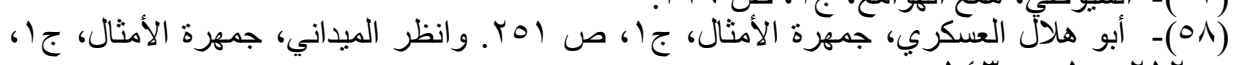

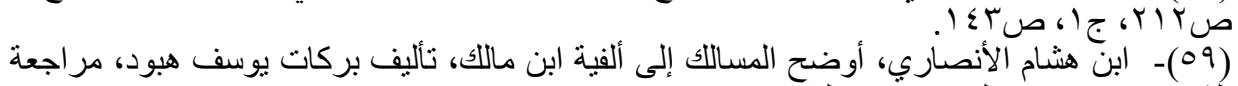

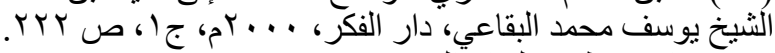

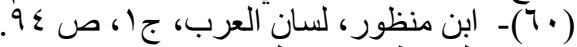

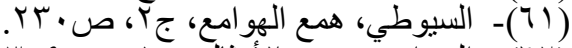

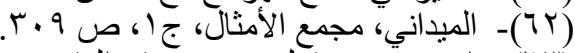

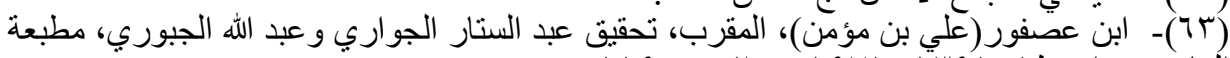

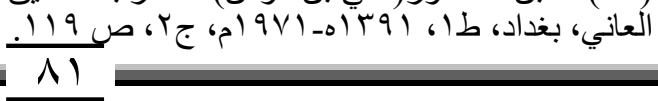


خوطب بها المذكر و المؤنث والاثنان و الجمع، و إنّما التزم فيه ذلك لأنَّ الأمثال لا تغيّر

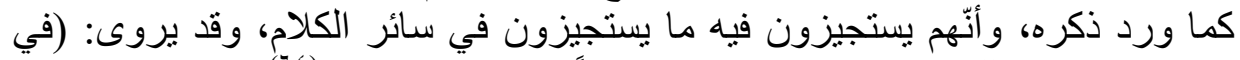

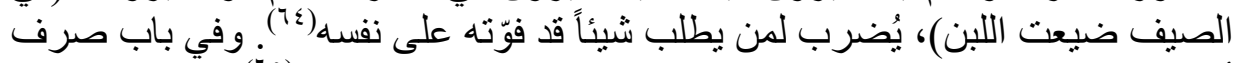

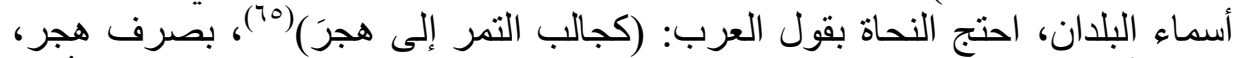

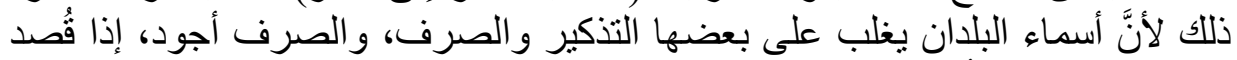

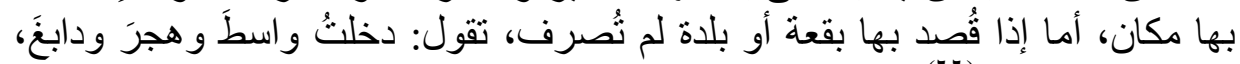

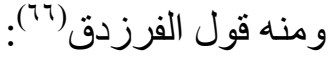

\section{مِنْهُنّ أيامُ صدقِ قد عُرفت بها * أيامُ و اسطَ والأيامُ من هَجَر ا}

وورد هذا المثل الذي نحن بصدده بصيغة أخرى وهي: (كمستبضع التمر إلى الى إنى

هجرَ)، ويُضرب هذا المثل لأنَّ هجر معدن التمر و المستبضع إلّيه مخطئ.

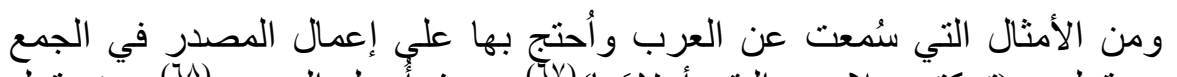

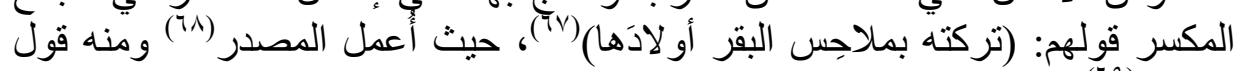
الثناعر (79):

و عدتَّ وكان الخلفُ منك سجيةً * مو اعيدُ عُرُقُوبٍ أخاهُ بيثربَ

ومعنى هذا المثل: تركته بالمكان الققر الذي لا يُدرى أين هو.

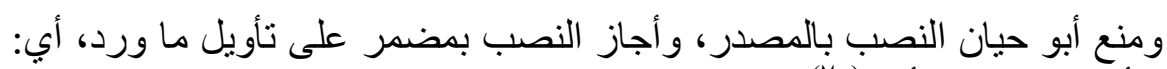
لحست أولادها، وو عد أخاه (vن).

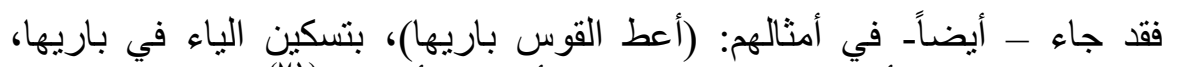

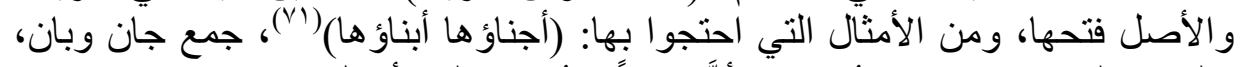

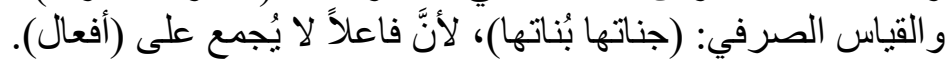

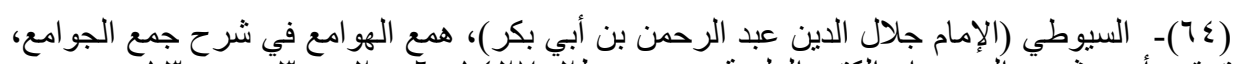

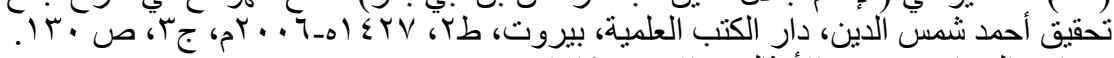

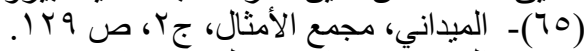

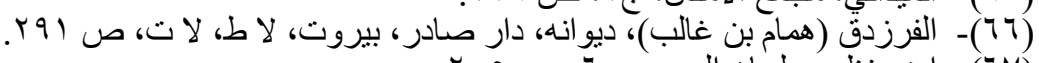

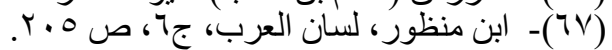

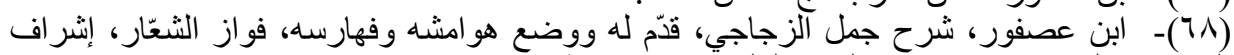

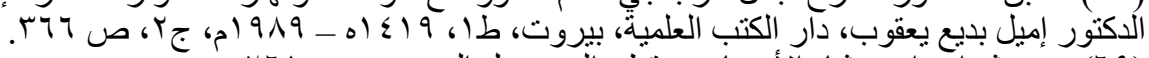

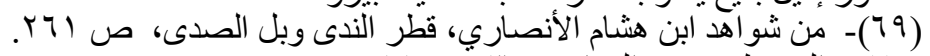
(V.)

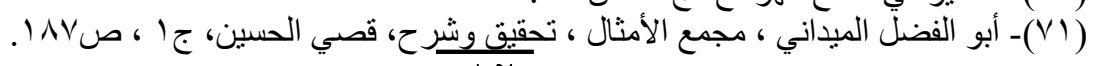




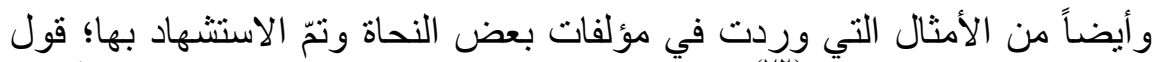

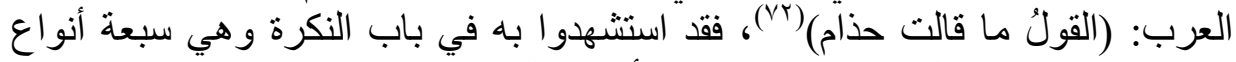

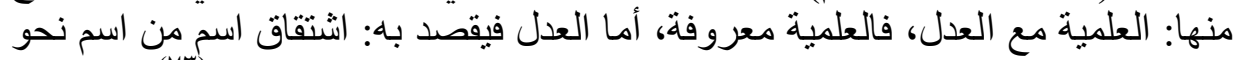

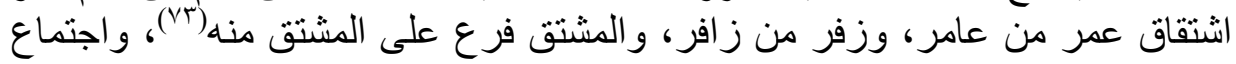
العلمية مع العدل يكون في مواضع معينة يمنع الاسم خلالها من الصرف فرف ورن هذه المو اضع هي:

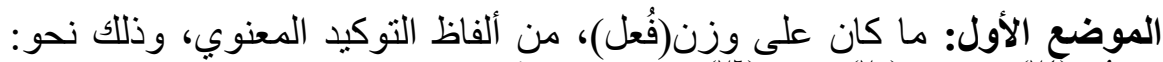

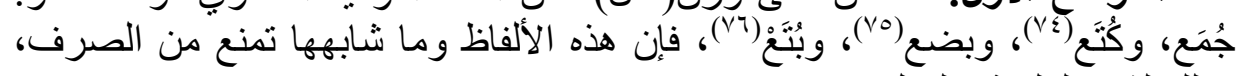
وذللك لثبه العلمية و العدل.

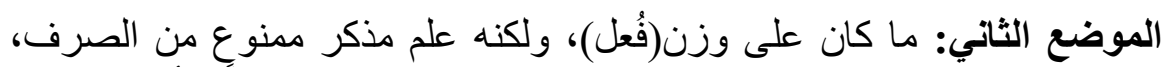

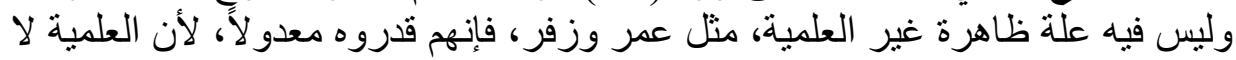

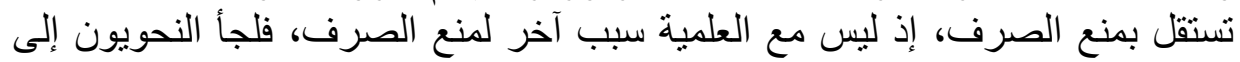

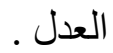

الموضع الثالث: لفظ(سحر)، الملازم للظرفية، وهو وقت وقت معين بعينه ملازم

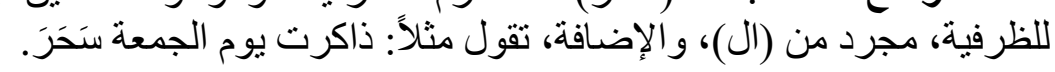

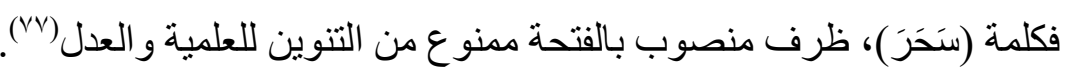

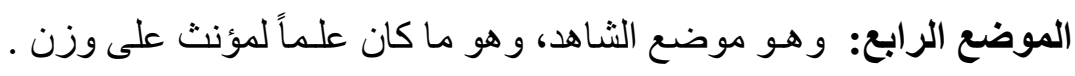

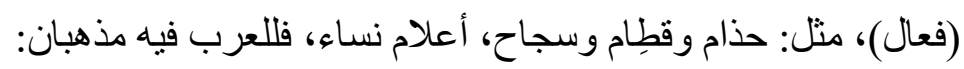

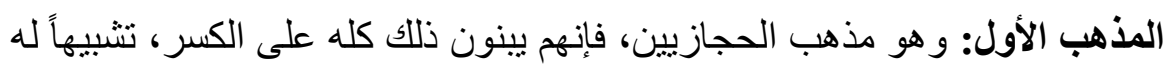

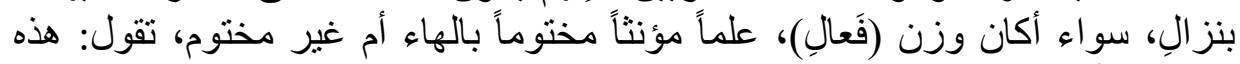

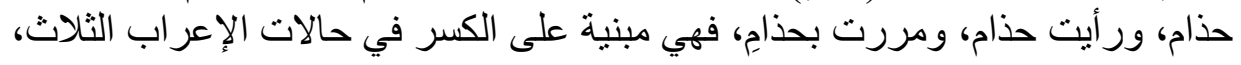

(VYr) (VT)

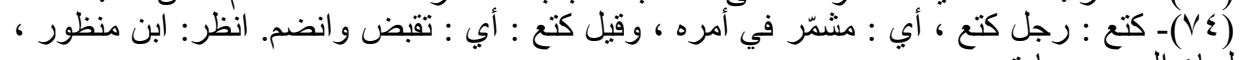

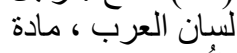

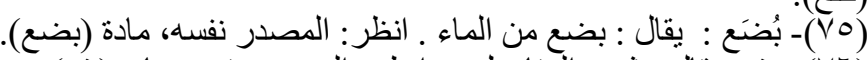

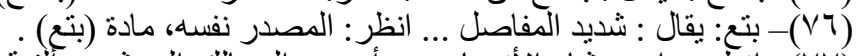
(VV) 


$$
\text { ومن صور ذلك ما ورد في قول الثناعر (ل⿳亠口冋.): }
$$

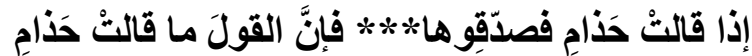

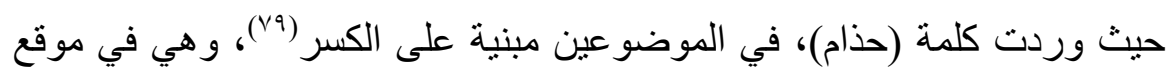

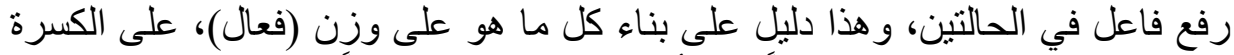
عند الحجازيين، إذ لو كان معرباً للزم أن يرفع بالفاعلية ظاهراً، ونظير هذا البيت قول

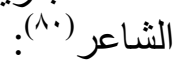

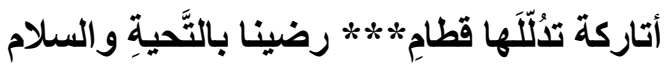

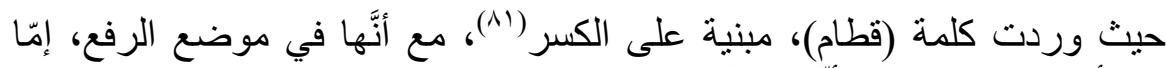

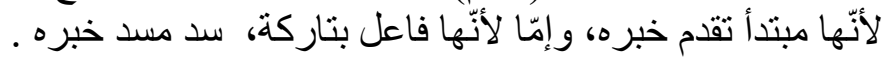

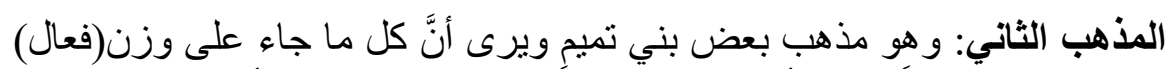

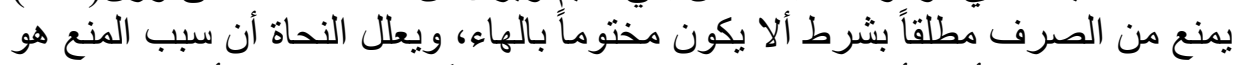

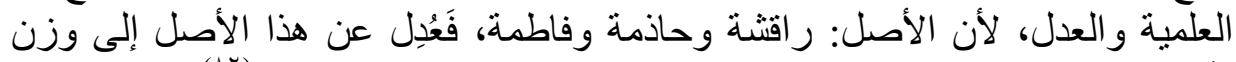

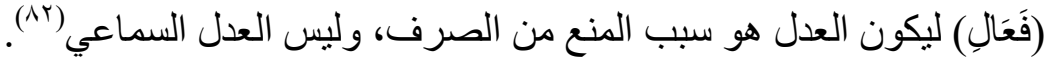

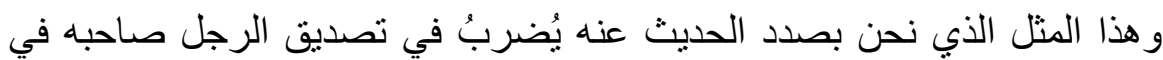

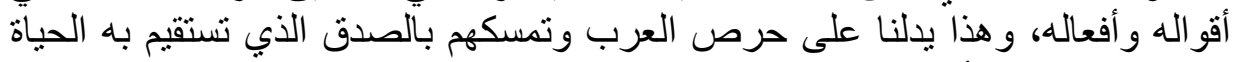

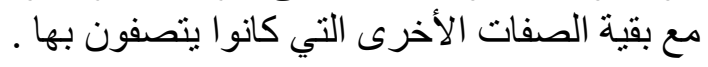

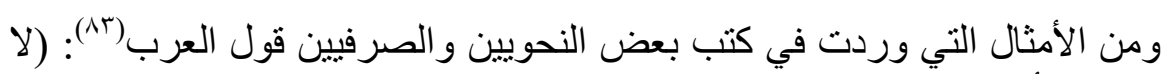

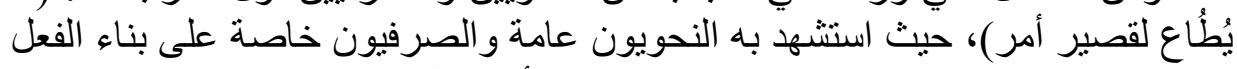
المضارع المعتل الوسط للمجهول، فمن المعروف أن الفعل المضار علئ بصفة عامة عندما

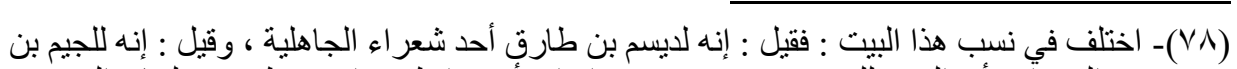

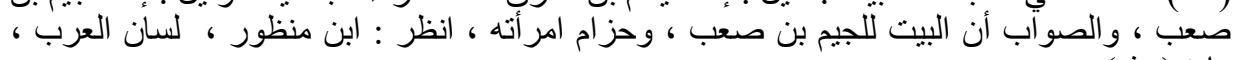

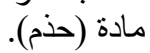

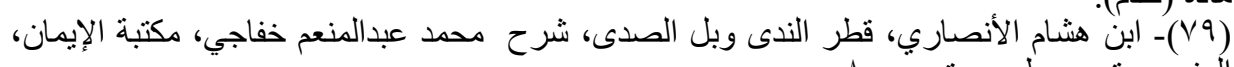

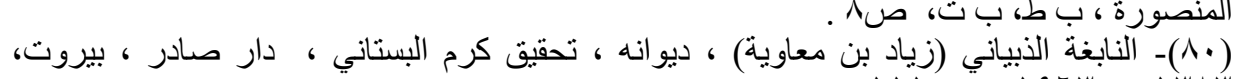

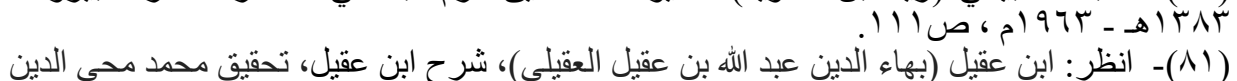

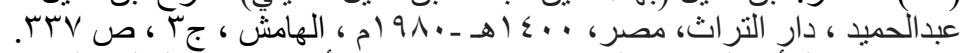

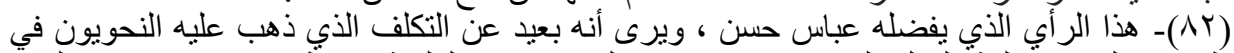

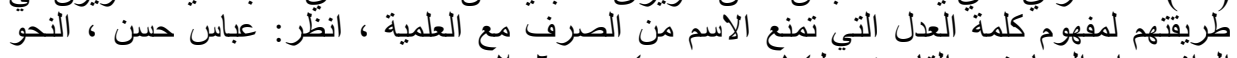

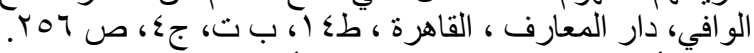
ا 


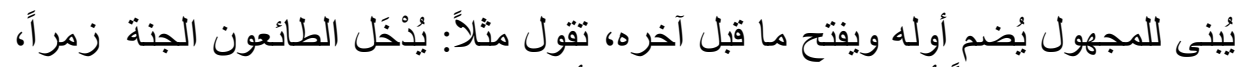

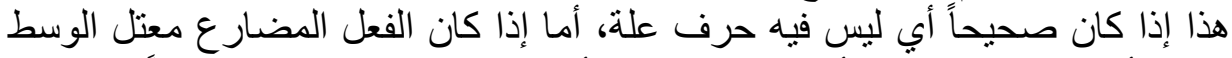

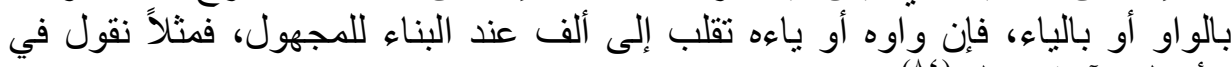

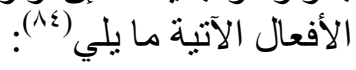

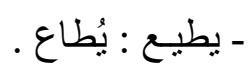

- يبيع : يُباع ، انقلبت الياء ألفاً .

$$
\text { - يقول : يُقال . }
$$

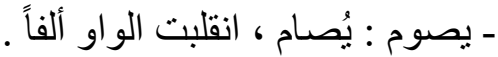

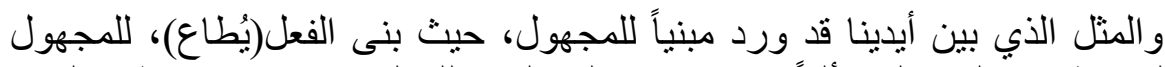

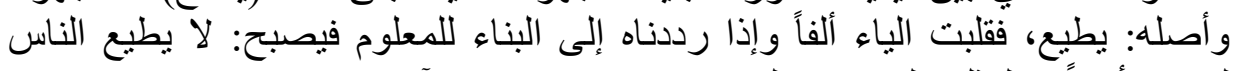

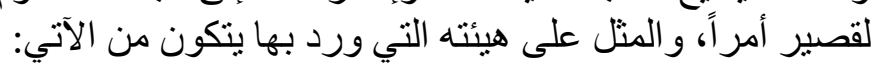

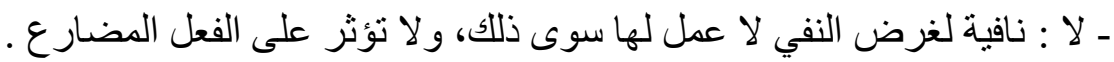

$$
\text { ـ ـ لُطاع: فعل مضار ع مبني للهجهول، و أصله (يطيع). }
$$

ـ أمرُ: نائب فاعل للفعل (بطاع) مرفوع بالضمة الظاهرة.

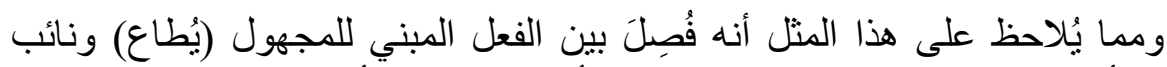

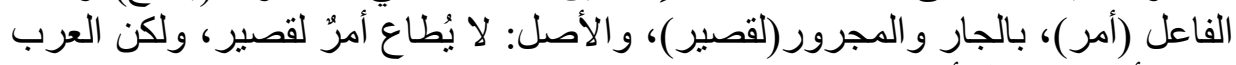

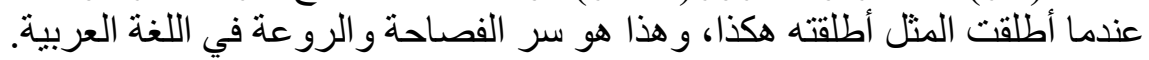

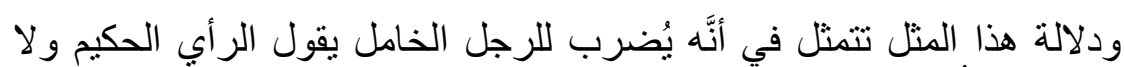

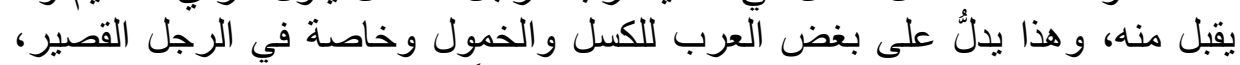

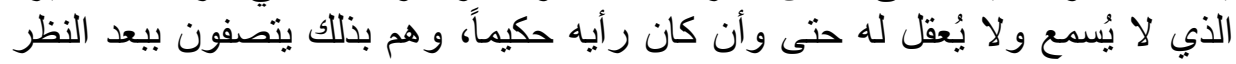

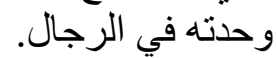

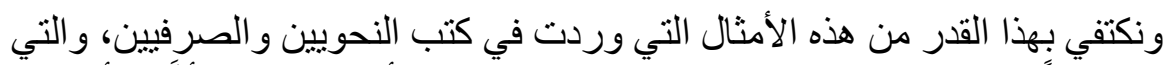

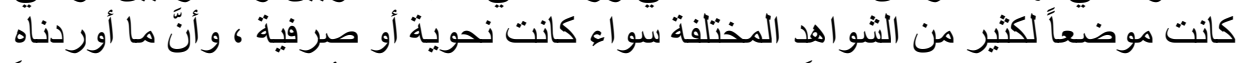

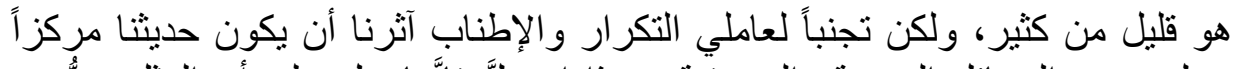

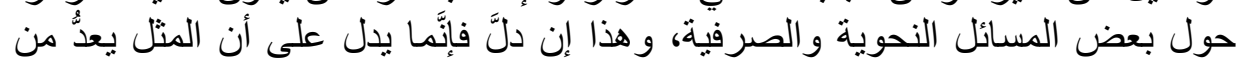

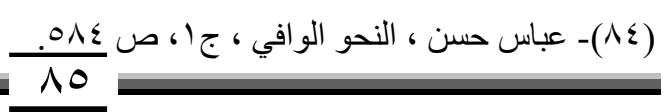


مصادر الاستشهاد الأربعة بعد القرآن الكريم والحديث النبوي الثريف و الثُعر العربي . الخاتمة : الخما

الحمد لله رب العالمين، و الصلاة والسلام على سيّدنا محمد بن عبد الله و على آله وصحبه ومن و الاه وبعد.

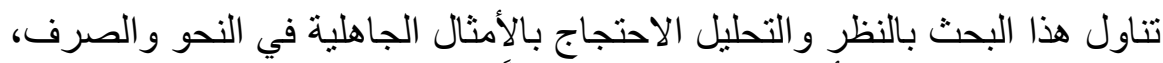

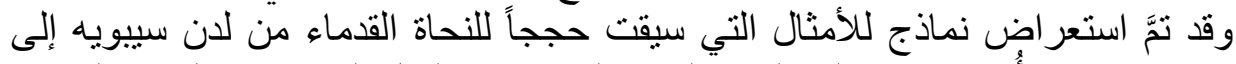

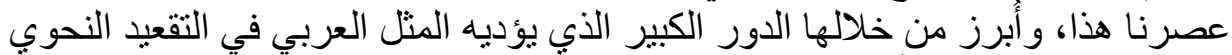
و الصرفي بوصفه واحداً من مصادر الاحتجاج، وُتُوصل إلى جلى جملة من النتائج أهمها:

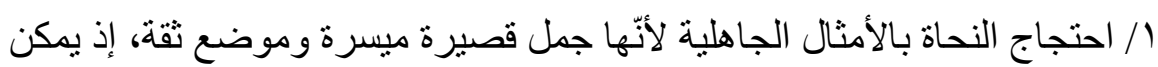
أن تتحقق فيها المشافهة. r / ليس هنالك خلاف حول الاحتجاج بالمثل العربي لا من حيث الزمان و لا المكان.

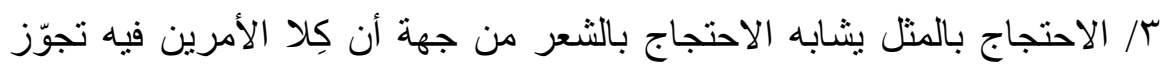
الضرورة فيه ليطرد مع القاعدة. ع / المثل المختلف في رو ايته لا يُحتج بهـ و وإنَّما يتمثل به.

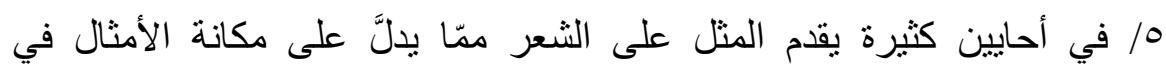
الاحتجاج.

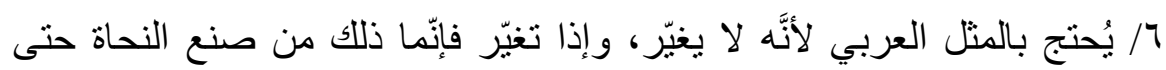

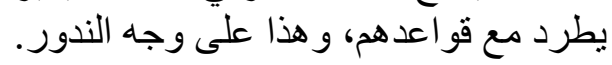

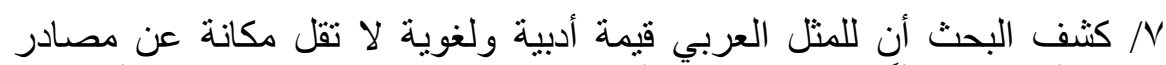

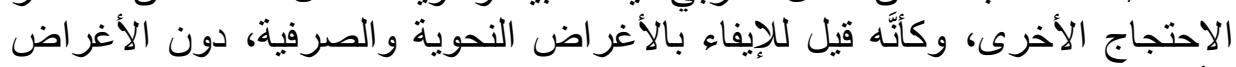

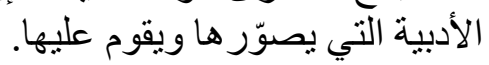
1/ الاحتجاج بالأمثال في القضايا النحوية أكثر منها في القضايا الصرفية. 
المصادر والمراجع

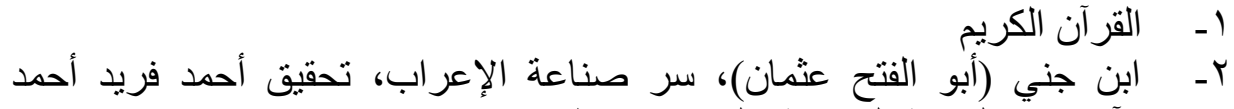

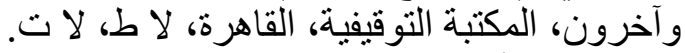

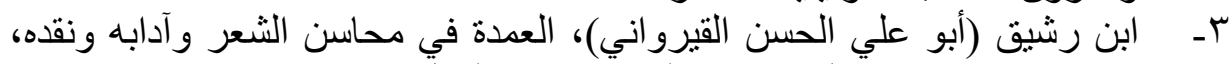

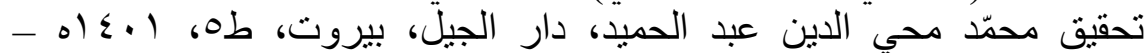
اين 9191

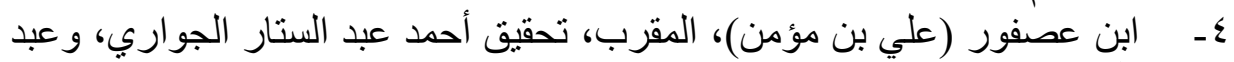

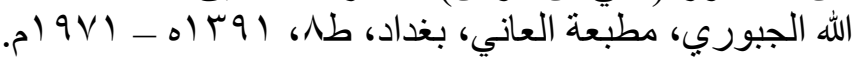

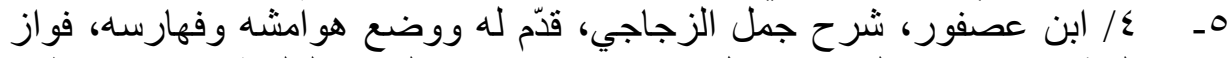

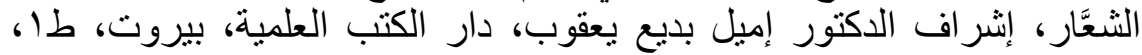

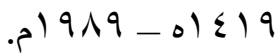

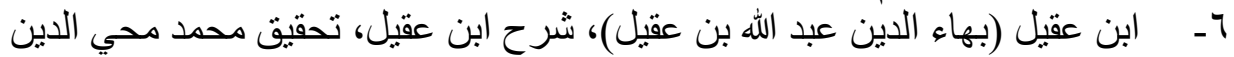

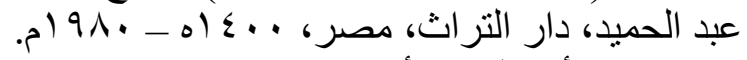

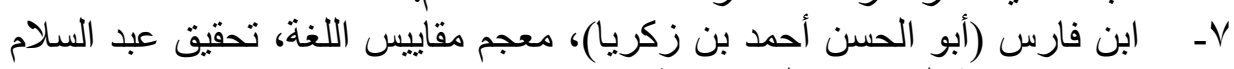

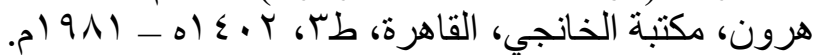

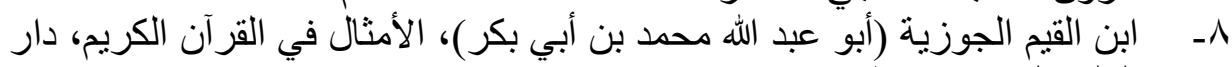

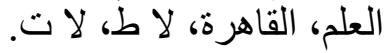

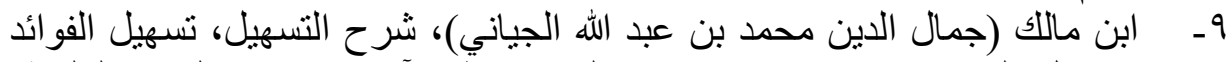

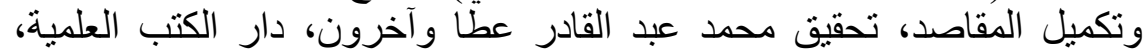

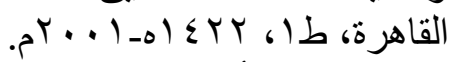

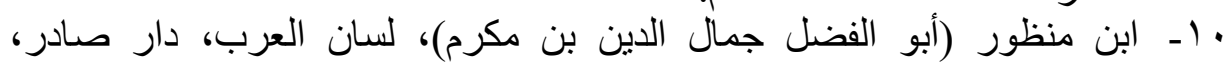

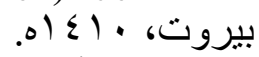

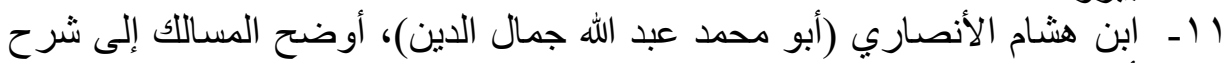

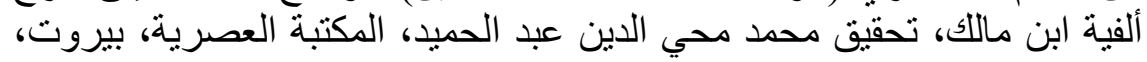

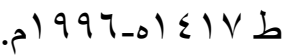

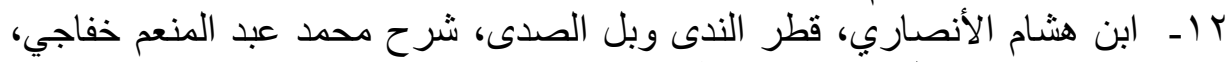

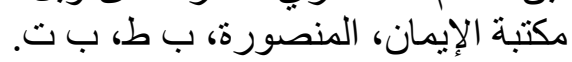

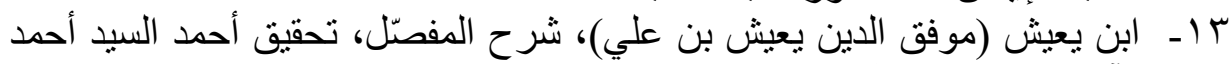

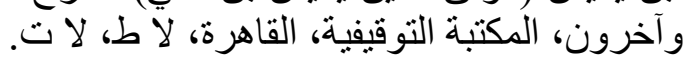
ع ا ــ أبو هلال آخون، العسكري (الحسن بن عبد الله)، جمهرة الأمثال، دار الجيل، بيروت،

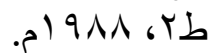
1 اـ الأشموني (علي بن محمد)، شرح الأشموني على ألفية ابن مالك، تحقيق محد $\Lambda \vee$ 
محي الدين عبد الحميد، شركة مكتبة مطبعة مصطفى البابي الحلبي، 7 باهـ ( ) 987 7 ا ـ حسن محمد شرف، الوسيط في تصريف الأفعال، دار الثقافة العربية، القاهرة،

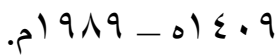

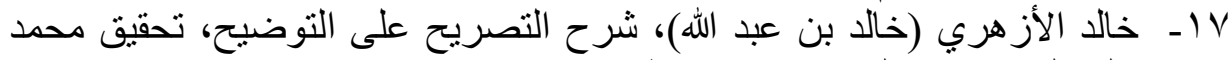

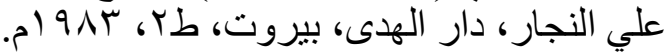

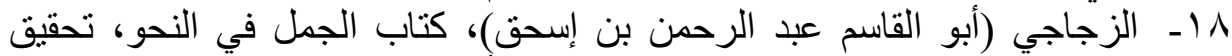

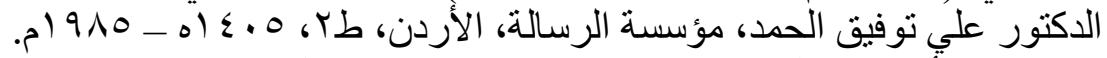

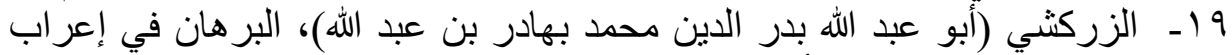

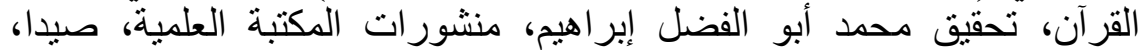

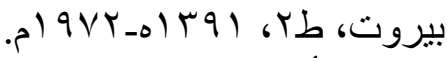

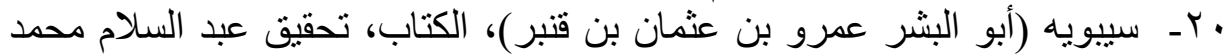

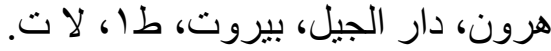

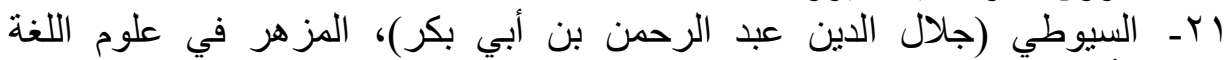

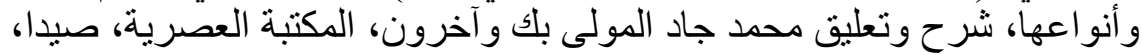

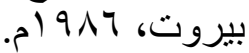

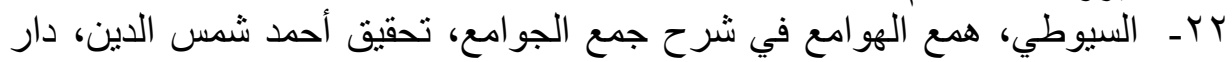

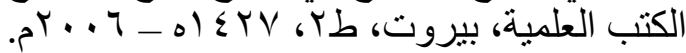

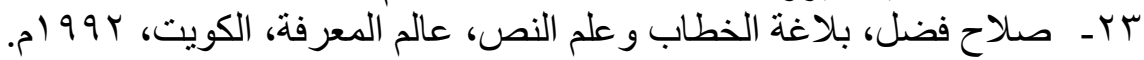

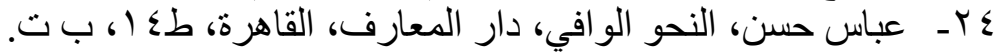

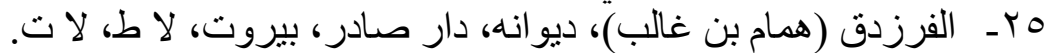

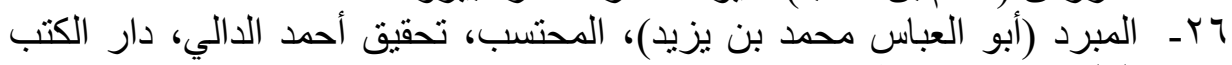

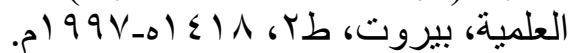
TV

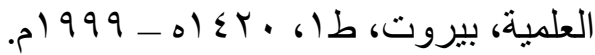

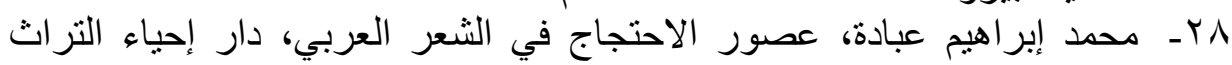

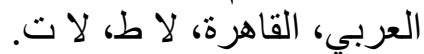

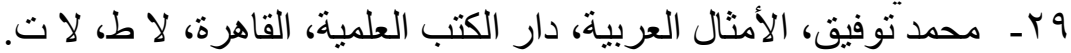

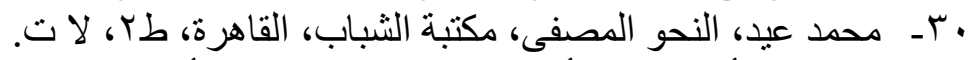

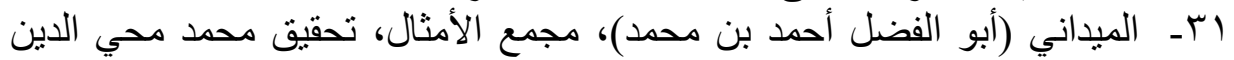

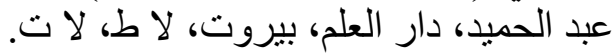

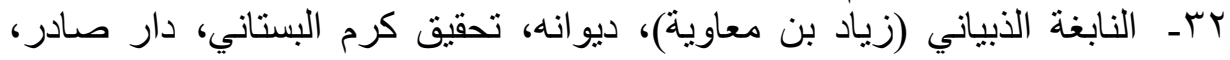

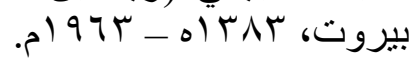

